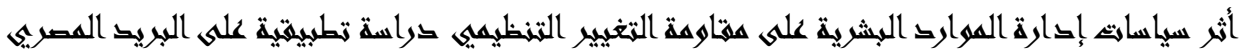

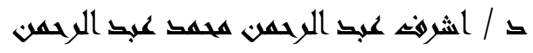

أثر سياسات إدارة الموارد البشرية على مقاومة التغيير التظظيمي

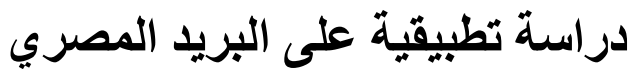

The Impact Of Human Resource Management Policies On Resistance Of Organizational Change An Applied Study On the Egyptian Post

$$
\text { مدرس إدارة الاعمال كلية التجارة جدمن الرحمة عبد الرحمن }
$$

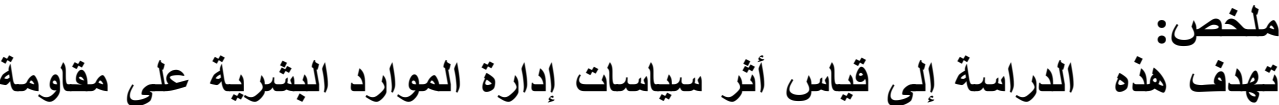

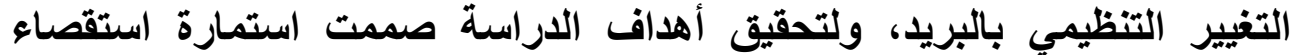

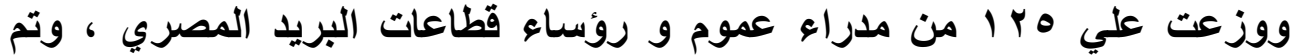

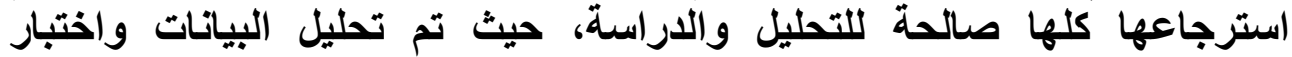

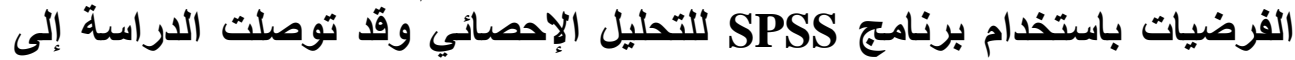

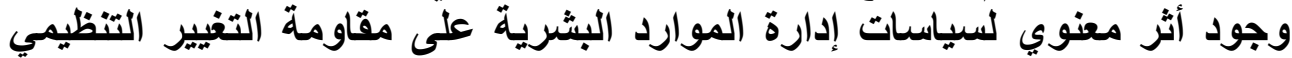

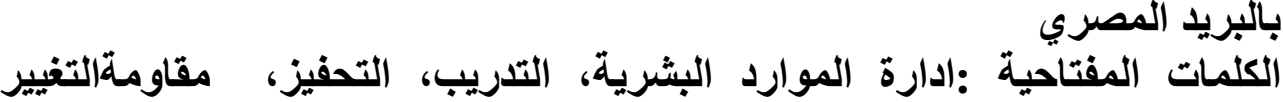

\title{
Abstract:
}

This study aims to study the impact of implementing Policies of human resources management $\mathrm{ON}$ resist organizational change resistance in Egyptian post, and to achieve the objectives of the study, a survey questionnaire was designed and distributed to 125 general managers and heads of Egyptian post sectors, all of which were retrieved for analysis and study, as the data were analyzed and hypotheses tested using the SPSS program for statistical analysis. The existence of an impact of human

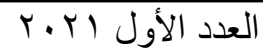

المجلد الثاني عشر 


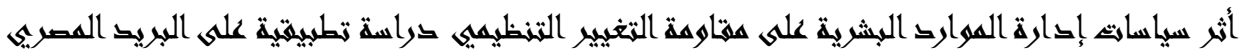

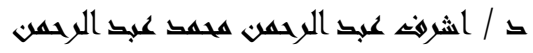

resources management policies on resisting organizational change in Egyptian Post

Key words: human resource management, training, motivation, resistance to organizational change

يقع على عاتق إدارة الموارد البشرية بمؤسسات الأعمال عبئاً كبيراً لإنجاح عملية

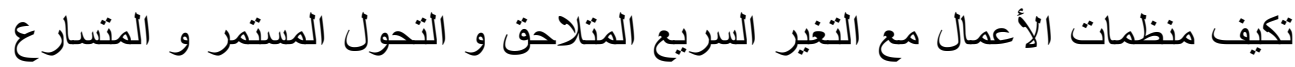
في بيئة الأعمال الخارجية و الذي هو سمة الألفية الجديدة و الذي وضع الذئع المنظمات

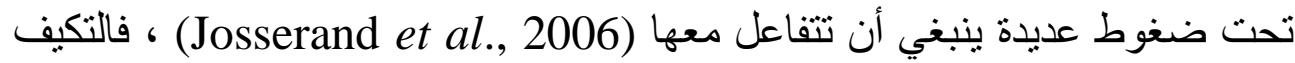
السريع مع الظروف المحيطة المتغيرة أصبح ضرورياً و ملحاً من أجل البقاء و تحقيق

الأهداف (Tushman and O'Reilly, 2013)

ودور ممارسات إدارة الموارد البشرية ضروري جداً لإعداد العاملين لهذا التغيير و

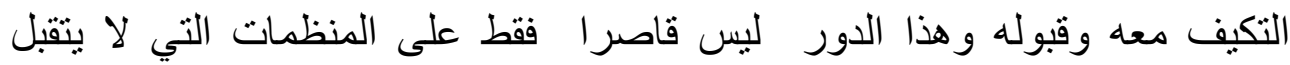

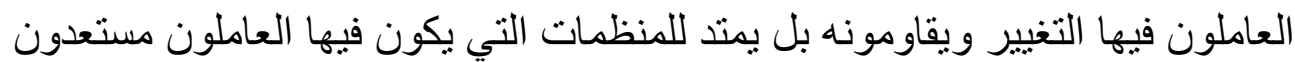

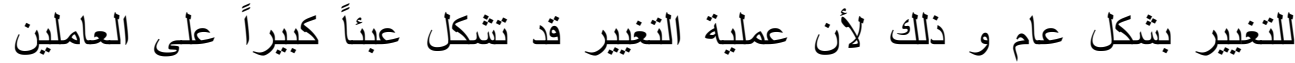

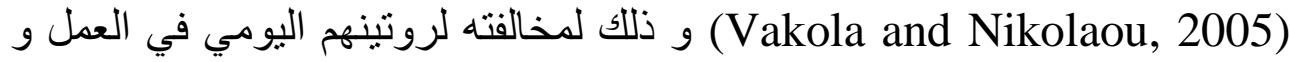

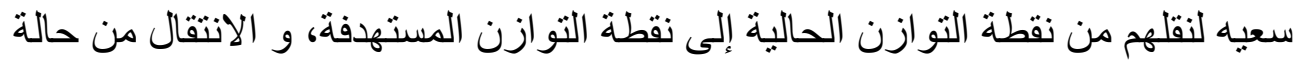

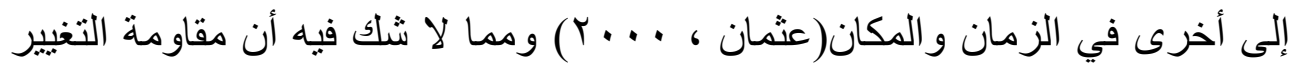

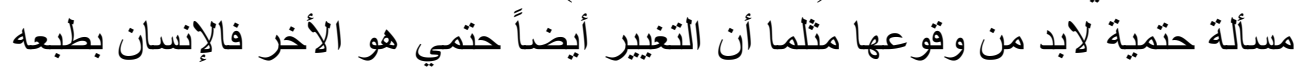
يميل إلى مقاومة تغيير الوضع الراهن لما قد بيسبه التغيير من إرباك والك وازعاج.

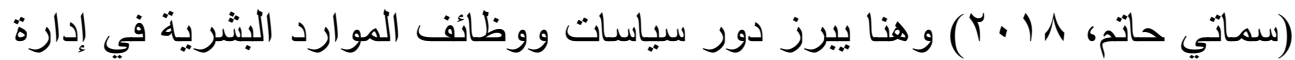
هذا التغبير و منع مقاومته بل و قبوله و القبول باته بالتغيير يزداد عندما بلبي منطلبات الأفراد، ويقدم الدعم والمساعدة لهم، مع تحديد مسؤولية كل فرد بدوره في في التغيير

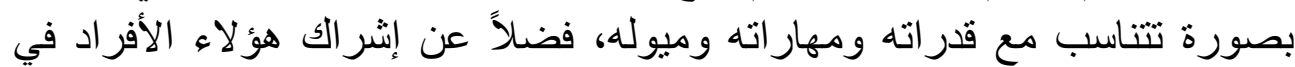

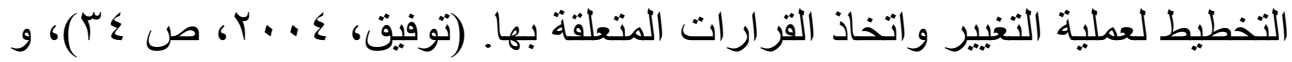




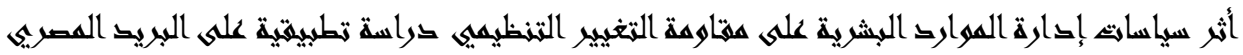

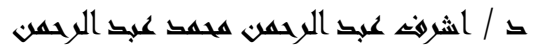

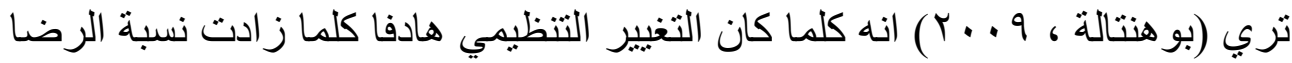
الوظيفي للعامل داخل المؤسسة عنه.

و يري (Combs et al., 2006) و(Wright et al., 2005) أن هنالك ممارسات محددة لإدارة الموارد البشرية و منها التدريب و العمل بروح الفريق لها بالغ الأثر الثرات

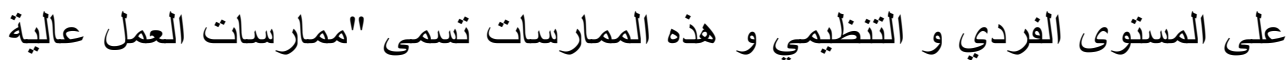

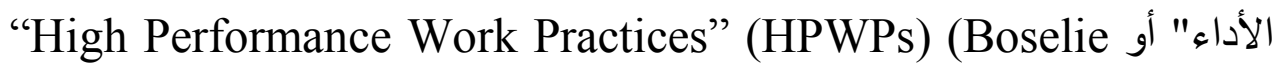
كما يعد التحفيز بشقية المادي و المعنوي أيضاً من ممارسات العمل et al., 2005) عالية الاداء فمن خلال التحفيز يتم توجيه و تنشيط وتركيز جهود العاملين نحو تحقيق الأهدافRobbins and Coulter (2007:253 و في هذا البحث سيتناول الباحث اهمية ممارسات ادارة الموارد البشرية في الحد من مقاومة التغيير داخل منظمات

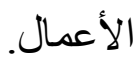

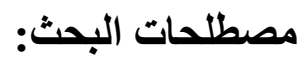
إدارة الموارد البشرية human resources management: هي عملية اكتساب وتدريب وتقييم وتعويض الموظفين ، مع الاهتمام بعلاقاتهم في العمل

وصحتهم وسلامتهم ، و إنصافهم.(Dessler,2017) كما تعرف بأنها (تخطيط وتنظيم وتوجيه ورقابة الأنشطة المتعلقة باختيار وتعبين

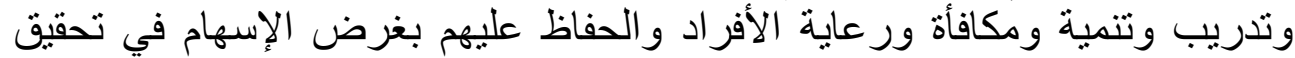

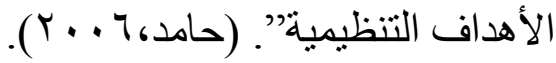

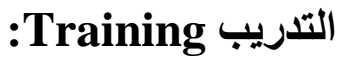
يعرف بأنه عملية تزويد العاملين بالمعارف و المهار ات اللازمة لأداء وظائف محددة (Elnaga, A.,\& Imran, A., 2013) و هو جهذ منظم ومخطط له بكل دقة و عناية لمساعدة المتدربين على اكتساب الكفايات المعرفية هو جانة و الأدائية والقيمية التي يحتاجها كل منهم في النماء و التكيف واداء الادوار و المهام

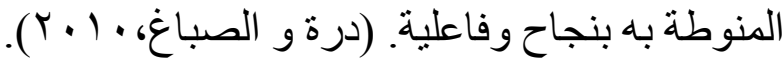




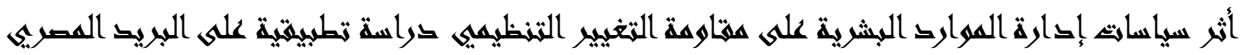

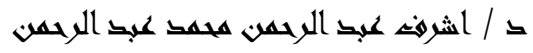

\section{التحفيز Motivation}

مقابل مادي ومعنوي يقدم للأفر اد كتعويض عن أدائهم المتميز، ويسمى هذا التعويض بالحافز أو المكافأة، ويحتاج الأمر قباس أداء العاملين في المنظمة بحيث بكون الحافز على قدر الكفاءة في الأداء (ماهر ،9 . . r) و تعرف الحوافز بأنها محركات خارجية للفرد تعمل على إثارة الحاجة و تقوية شدة إلحاحها، و قد تكون الحوافز مادية كالمكافآت و زيادة الر اتب و المنافع المادية الأخرى، أو تكون معنوية كزيادة السلطة أو الحصول على لقب وغيرها من الأمور الهامة التي لا تقاس بمعابير مادية منثل

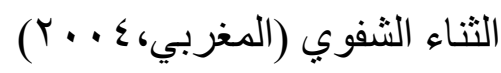

التغيبر (change

هو تحول جذري في الفكر بـتم فيـه الخروج من الطرق التقليدية و الأسـاليب المعتمدة إلى أسس وقيم واتجاهات جديدة تخاطب الفكر و العقل وتو اكب التطور وتلبي مطالبـه

(Fullan, 1993)

\section{إدارة التغيير Change Management}

هي ذللك التهج الإداري الذي بعنى برصد مؤشرات التغبير في بيئة منظمة الأعمال وفرز تللك المؤشرات التي لها علاقة بنشاط المنظمة ضمن أولويات إدارتها بهدف تكيف وتأقلم تللك الإدارة في ممارستها لوظائف العملية الإدارية مع المتغيرات المتوقعة لتحسين أدائها وسلوكها.(العتيبي، ب . . ب) و تعرف بأنها استراتيجية متطورة للتعليم تستهدف تغيير العقائد والاتجاهات و القيم

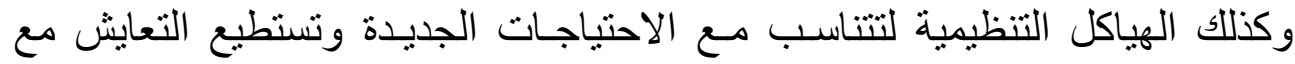
التحديات التي تفرضها التغييرات الهائلة في البيئة الاجتماعية والثقافية والاقتصادية

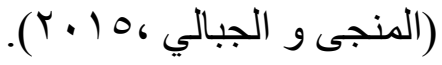

مقاومة التغيير Change resistance " وتعني مقاومة التغيير امتناع الأفراد عن التغيير، أو عدم الامتثال له بالدرجة

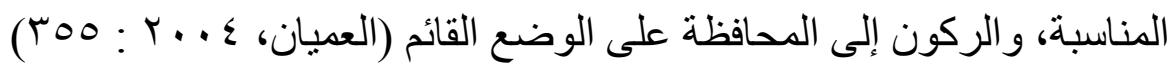




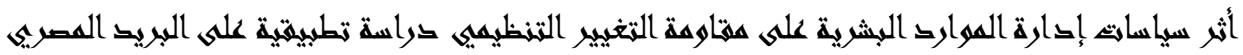

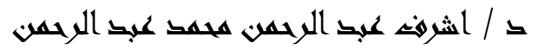

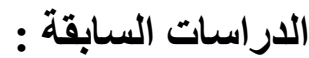

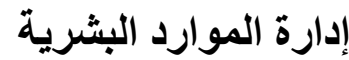

تعد إدارة المو ارد البشرية أساس كل العمليات الإدارية و لكنها لا تعد الأساس لعمليات

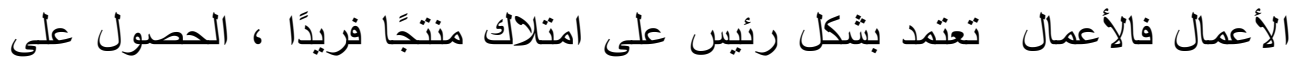

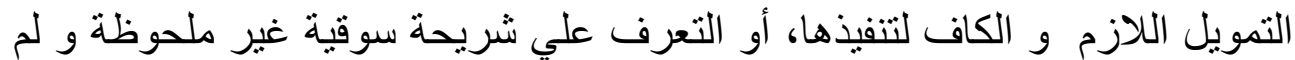

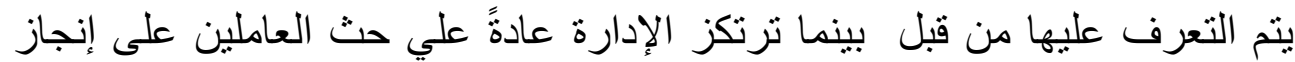
الأعمال بطريقة مثمرة ، تتسم بالكفاءة و الفاعلية مما يؤدي لرفاهية المنظمة و ولثة العاملين

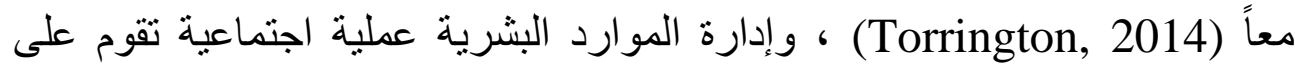

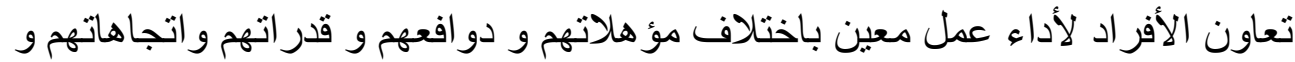

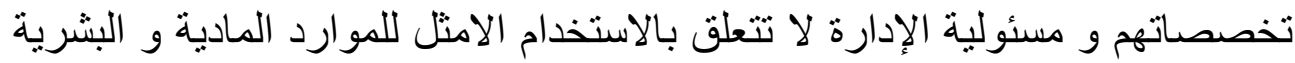

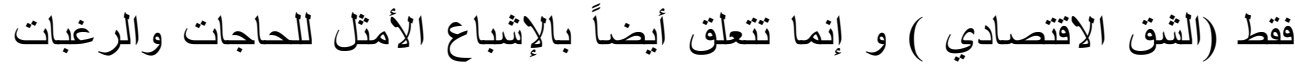

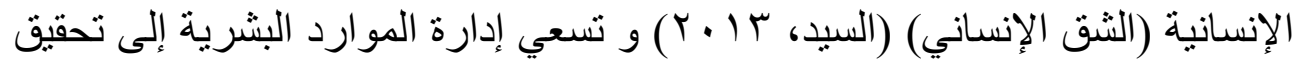

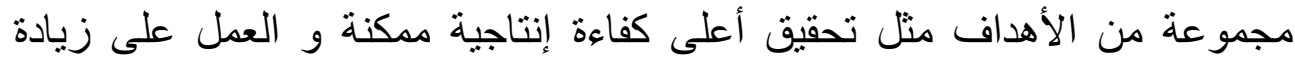

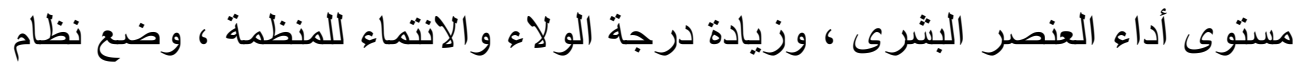

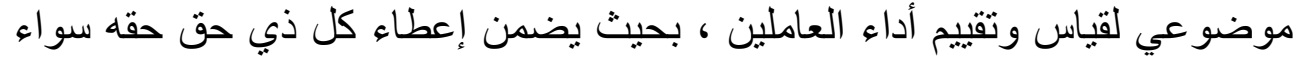

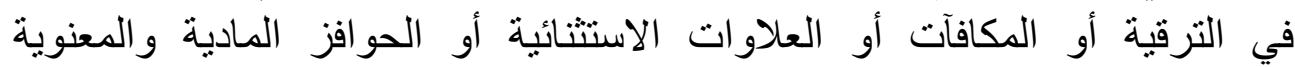

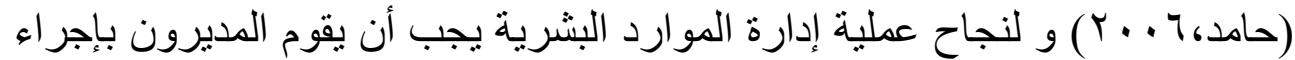

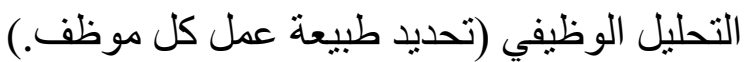
و اختيار المرشحين للوظيفة و تخطيط احتياجات العمل وتوظيف المرشحين للوظائف

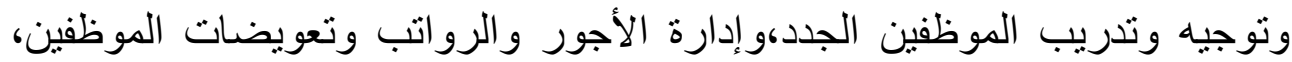

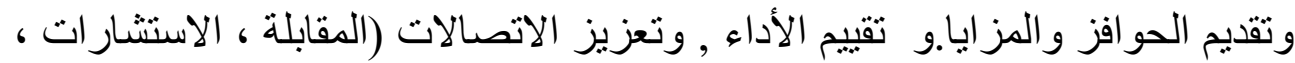

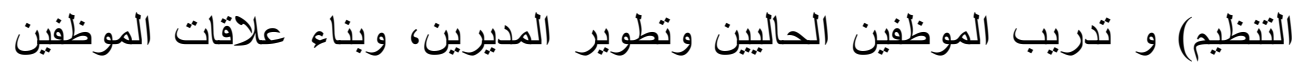

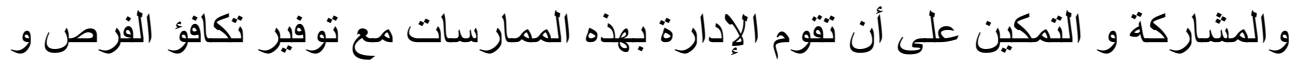
بيئة ايجابية للعمل والعدل مع الحفاظ على صحة الموظفين وسلامتهم . (Dessler,2017) 


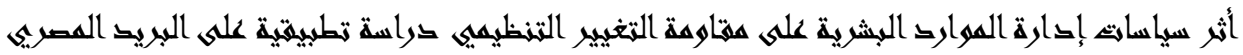

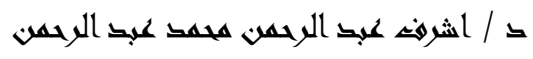

وتعد الإدارة الناجحة لعملية التغيير من خلال سياسات إدارة الموارد البشرية من أهم

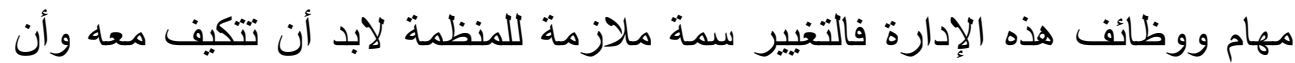

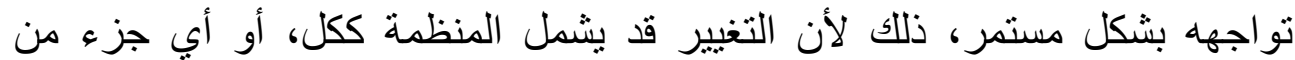
أجزائها فلابد أن تتعامل المنظمة مع التغيير بشكل سليم ومنظم ومخطط لضمان لضمان

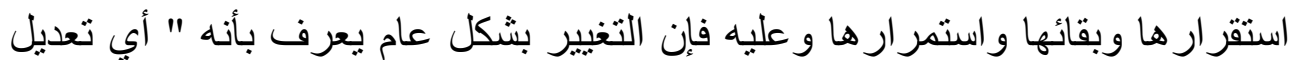

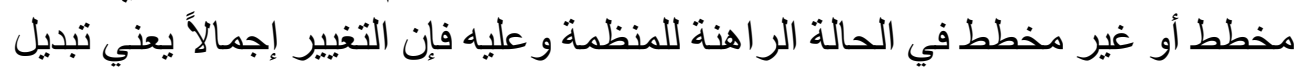

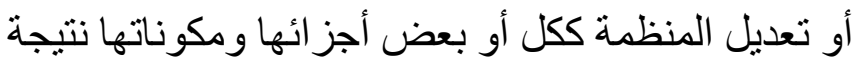

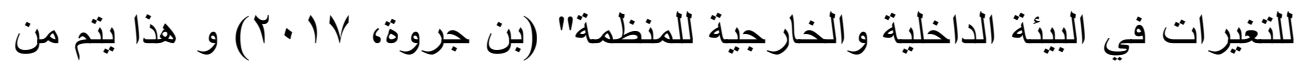
خلال سياسات إدارة المو ارد البشرية واختار الباحث منها سياستي التدريب و التحفيز

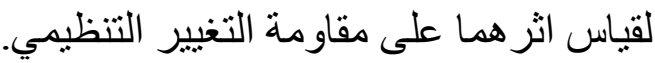

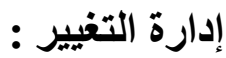

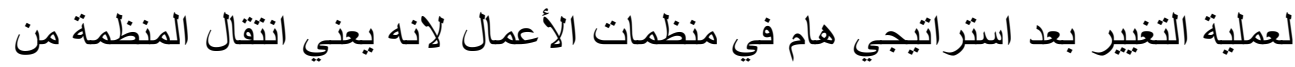

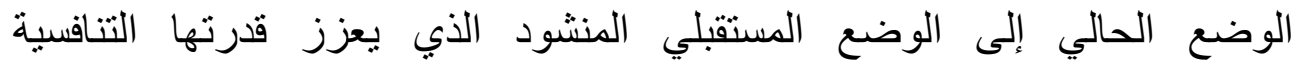
(Hill\&Jones2001) و يعد نجاح المنظمة في التكيف مع التغيير هو مفتاح البقاء

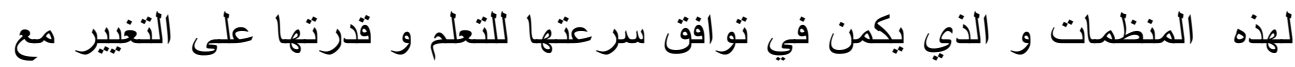

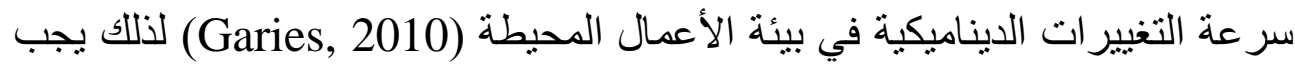

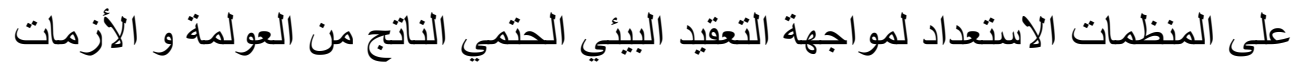

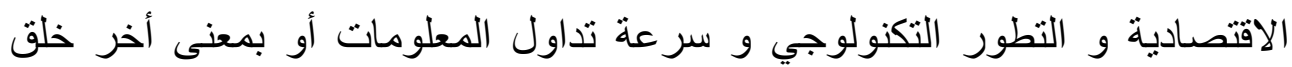

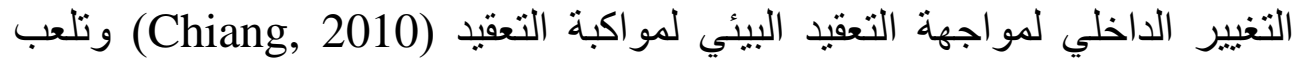

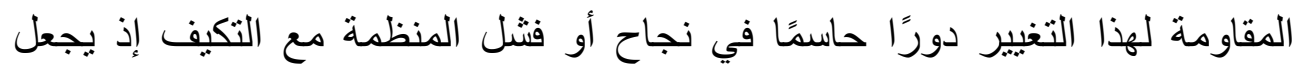
المنظمة واقعة تحت ضغوط من البيئتين الخارجية و الداخلية مما قد يؤثر علي ثباتهاو استقرار ها ( Sohal,1998\&Waddell ) و تهدف إدارة التغيير إلى تحقيق التلاؤم مع متغيرات البيئة الداخلية والخارجية المتسار عة بما يضمن للمؤسسة البقاء

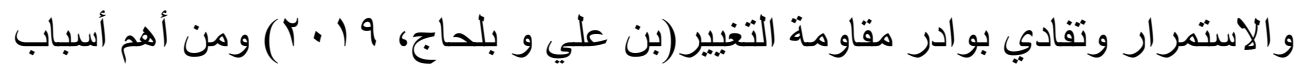

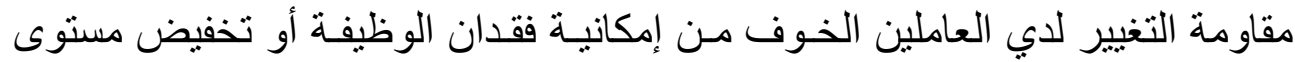




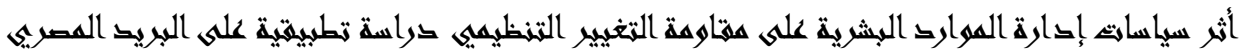

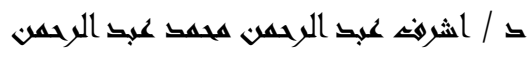

الاخل أو الزيادة في عبء العمل أو إدخال أساليب عمل حديثـة لا تتو افق مع قدر ات

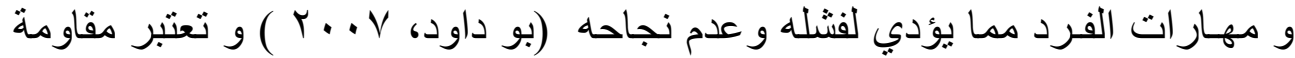

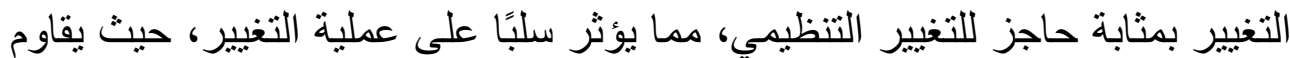
الموظفون التغييرات بسبب الخوف من التغيير في مكان عملهم ولكن بمكن أن تكون عاملاً هاماً في تحسين عملهم أثناء در احل التغيير (Halit Karakhsa, 2019). لذللك يجب أن تكون التغييرات المقدمة من جانب الإدارة هادفة وموجهة ومخططاً لها

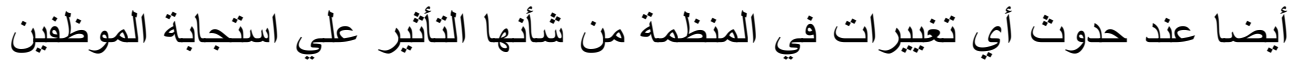

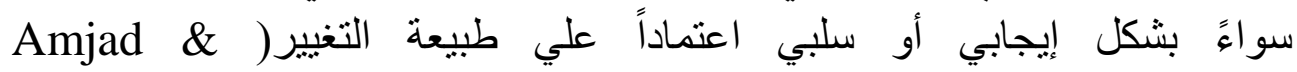
(Rehman,2018 و نجاح المنظمة في تطبيق سياسات الموارد البشرية له دور كبير في مواجهة مقاومة التغيير التنظيمي وذلك من خلال كثرة الدورات التكوينية حيث تعتبر من المهام الأساسية، فهي عملية تشمل جميع العاملين في الميدان الواحد مهما

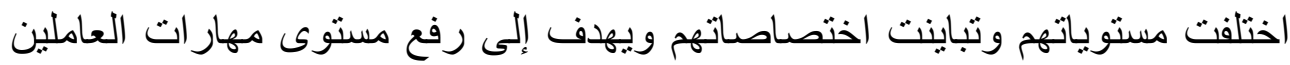

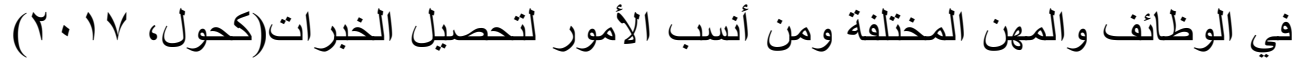

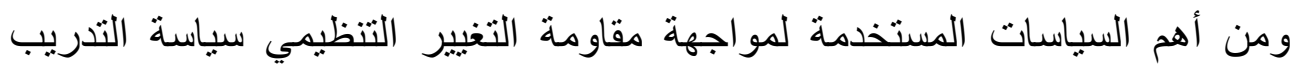

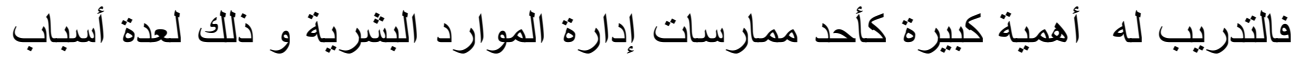

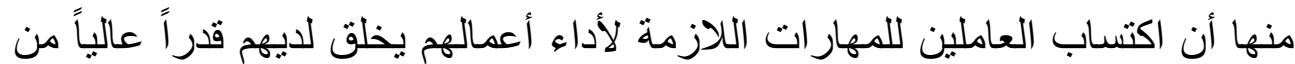
الثقة بالنفس ،ويؤثر بصورة كبيرة على الإنتاجية و يرفع أداء العاملين ويكسبهم الأداء

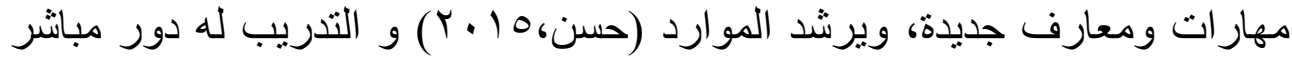

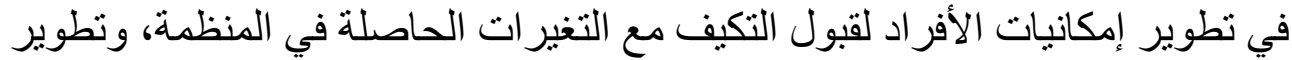

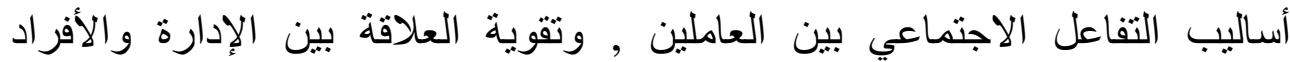

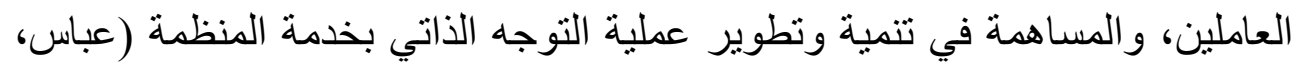

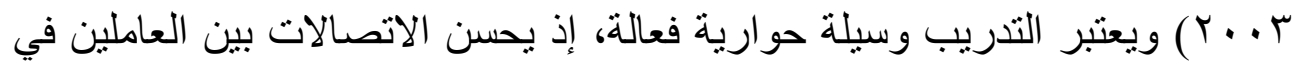

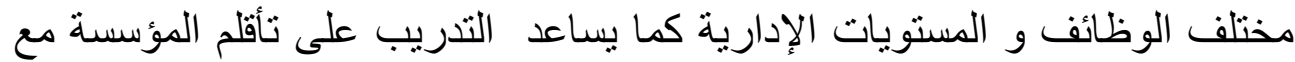
بيئتها، ويساهم في الحفاظ على بقاء المؤسسة قادرة على المنافسة، باعتباره الإهاء مجالاً

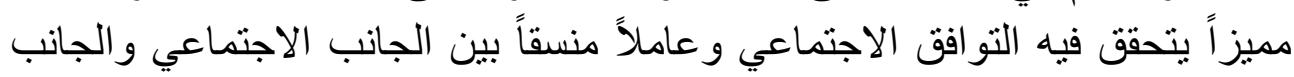




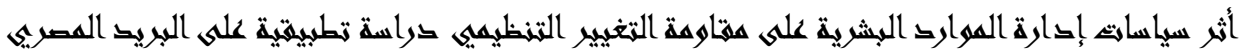

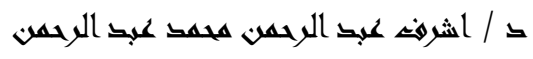

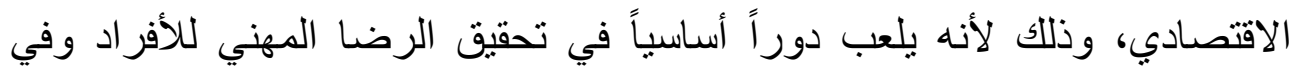

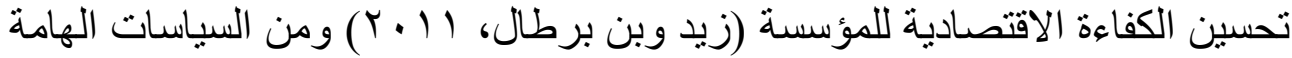

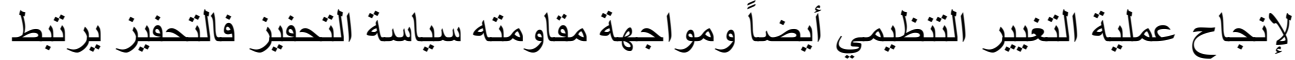

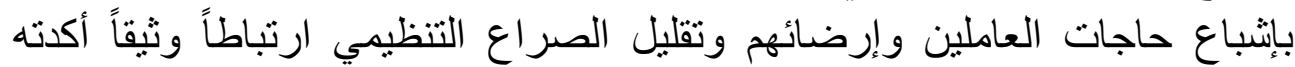

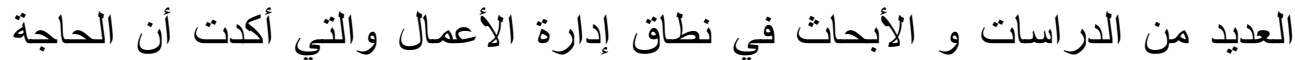

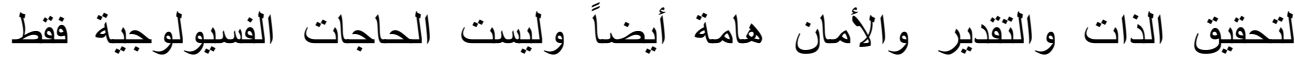

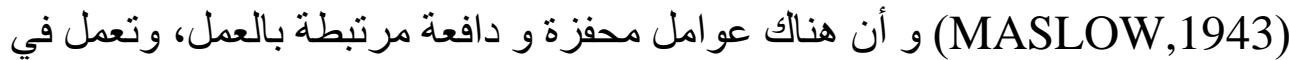
حالة وجودها على بناء درجة عالية من الرضا الوظيفي والشعور بالألامتنان عند

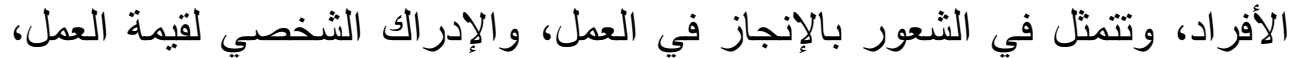

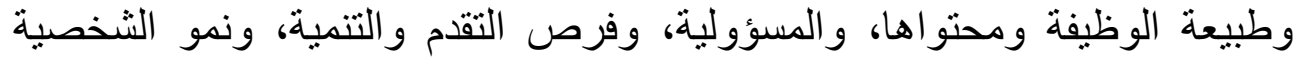

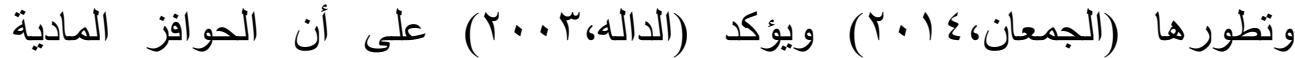
و أهمها(الترقيات و العلاو ات و الحوافز التشجيعية) و الحوافز التو المعنوية ومنها (الثناء الثفوي و خطابات الثكر والتقدير) لها دور كبير في تحسين اداء العاملين.

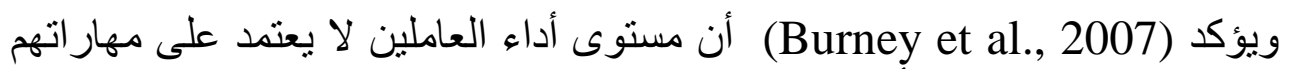

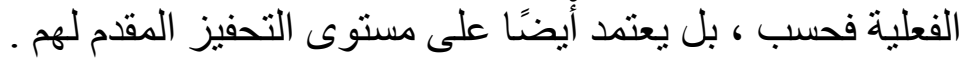

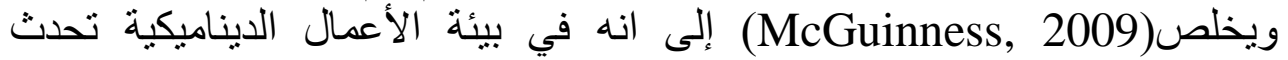
التغييرات باستمر ار لذا ينبغي أن يقوم المديرون بتحليل مستوى التحفيز لكل موظف، إلفه

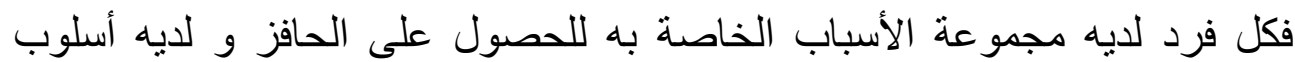
مفضل من التحفيز فبعض الأفراد يتم تحفيز هم من خلال العوامل المالية بينما يتم تحفيز الآخرين من خلال عوامل غير مالية فيجب تحديد الدوافع الداخلية والخارجية

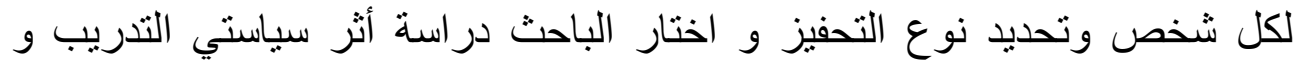

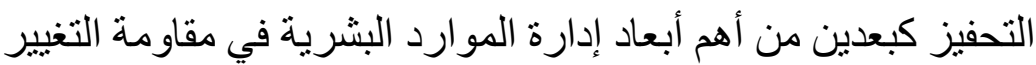




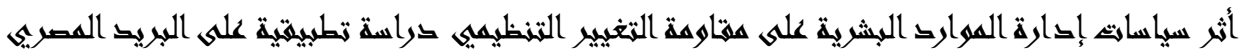

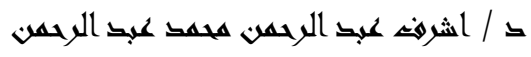

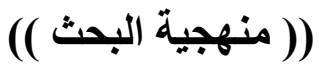

أولاً : مشكلة البحث

من خلال اطلاع الباحث على العديد من الأبحاث و الدر اسات السابقة و الوقوف على أهم نتائجها و تحليلها يمكن طر ح التساؤل الرئيس التالي ليمثل مشكلة الدر اسة و هو :ما مدى تأثير سياسات إدارة الموارد البشرية على مقاومة التغيير التظظيمي بالبريد

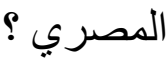

و يمكن تحديد أبعاد المشكلة و البحث من خلال التساؤلات التالية : • ما هي أهمية سياسات إدارة الموارد البشرية في تعزيز مقاومة التغيير التتظيمي؟ • ما هي مر احل و خطو ات تطبيق سياسات إدارة الموارد البشرية ؟ • هل سيصبح تطبيق سباسة التدريب كأحد سياسات إدارة الموارد البشرية دورياً ام هرئ سيكتفى بـه لمو اجهة مقاومة التغيير فقط ؟ هب هل إدارة التدريب بالبريد المصري لديها القدرة على إتمام عملية التدريب بنجاعة أم سيتم الاستعانة بمؤسسات متخصصة في التدريب ؟ مؤشرات قياس أداء العاملين هل هي دقيقة لضمان عدالة عملية التحفيز؟ هل يوجد تصور ورؤية معينين يحددان وسائل التحفيز المعنوي مع وسائل التحفيز

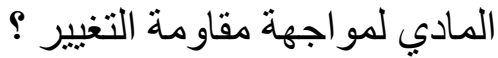

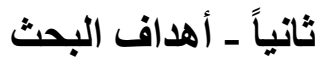

يتمثل الهدف الرئيس لهذا البحث في نجاح المنظمة في التكيف مع التغيير الخارجي من خلال تطبيت سياسات التدريب و التحفيز كسياستين من سياسات إدارة الموارد البشرية بالبريد المصري لمو اجهة التغيير التتظيمي الداخلي. و يثنمل الهدف الرئيس للبحث مجمو عة من الأهداف الفرعية تثمثل في ما بل:

نشر ثقافة مواجهة مقاومة التغيير التنظيمي بين القيادات . توضيح أهمبة مو اجهة مقاومة التغيير التتظيمي في نجاح التكيف مع بيئة

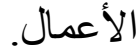




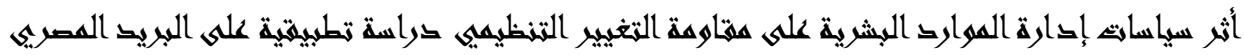

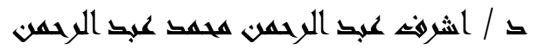

$$
\text { ترسيخ قير سياسة التدريب و استمر ارية تطبيقها بصفة دورية. }
$$

تطوير نظام التحفيز بشقيه المادي و المعنوي و عدالة تطبيقه واستخدامه وله

لمو اجهة مقاومة التغيير التنظيمي.

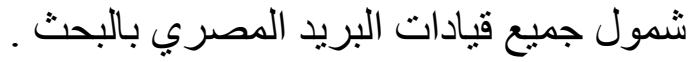

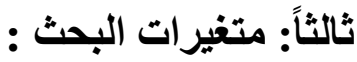

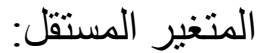

و الذي يتمثل في سياسات إدارة الموارد البشرية بالبريد المصري و اختار الباحث

منها التدريب و التحفيز

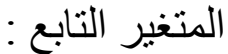

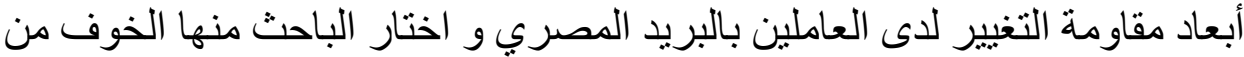
خسارة المركز الوظيفي و احتمال تخفيض اليض الدخل و والير الخوف من زيادة أعباء العمل. خامساً : منهجية البرة الوني الثكل ( (1) مخطط متغير ات البحث

المتغير التابع أبعاد مقاومة

المتغير المستقل سياسات

التغيير

إدارة الموارد البشرية

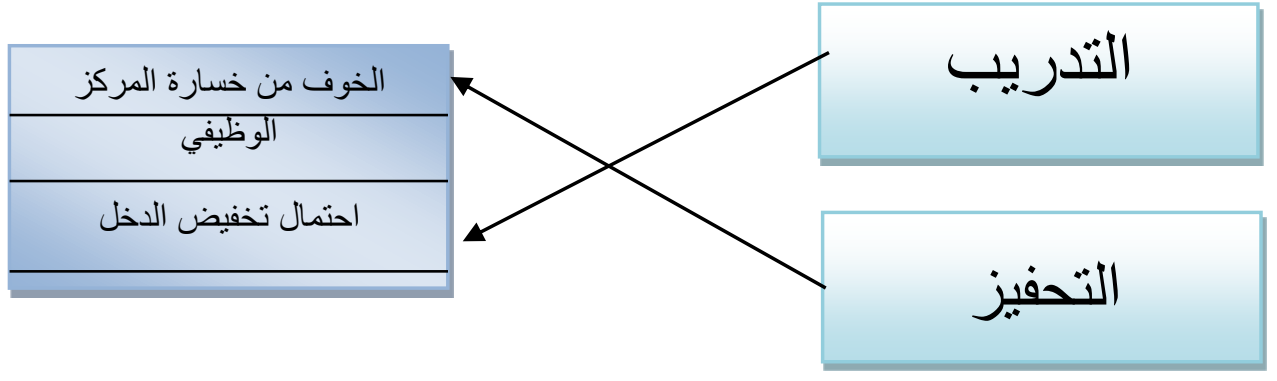

المصدر : اعداد الباحث

العدد الأول ابr.r

المجلد الثاني عشر 


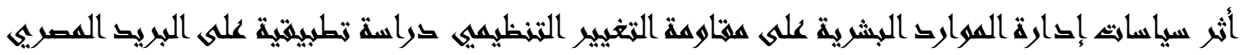

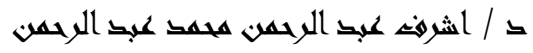

\section{رابعاً: فروض البحث : \\ يتمثل الفرض الرضئيس في ما فايلي:}

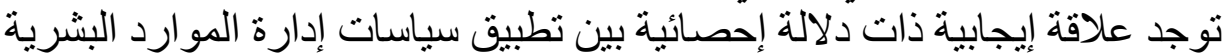

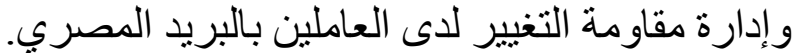

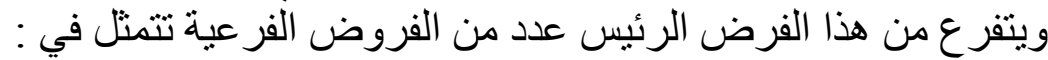

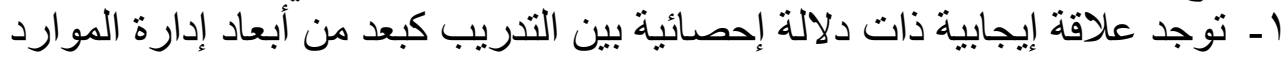

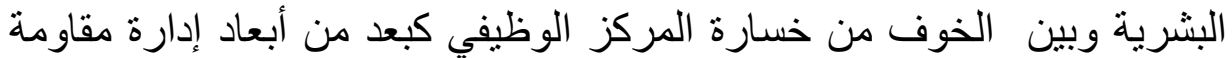

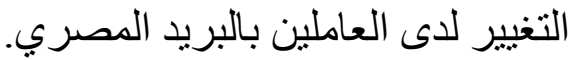

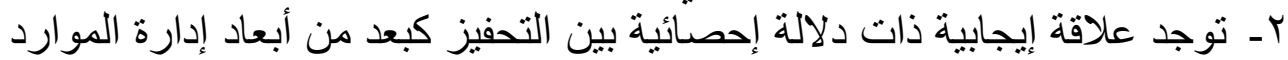

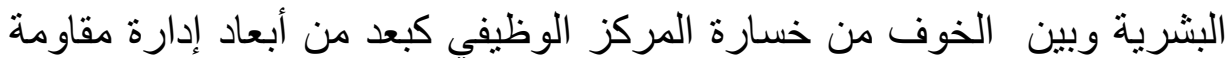
التغيير لادى العاملين بالبريد المصندي.

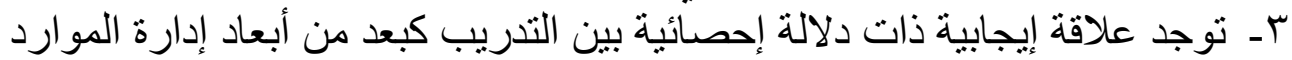

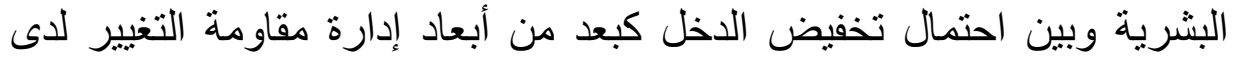

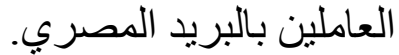

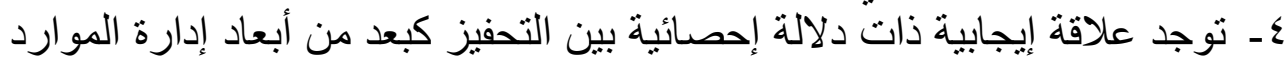

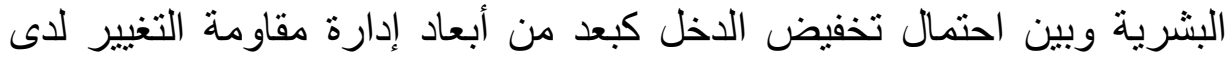

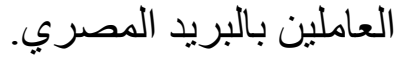

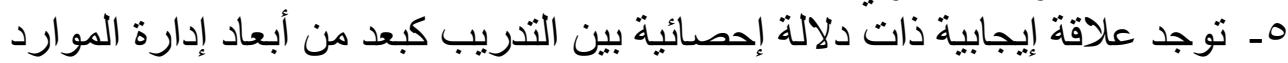

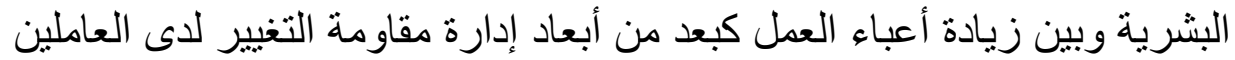
بالبريد المصري. 7 ـ ـ توجد علاقة إيجابية ذات دلالة إحصائية بين التحفيز كبعد من أبعاد إدارة الموارد

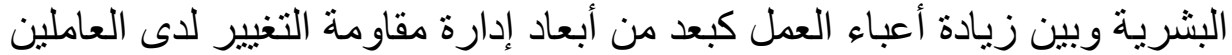
بالبريد المصري. خامساً_أهمية البحث اـ الأهمية العلمبية

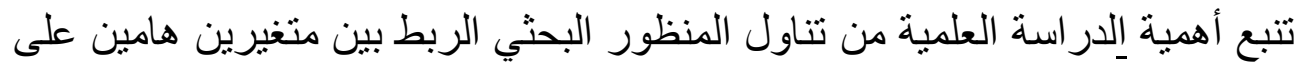

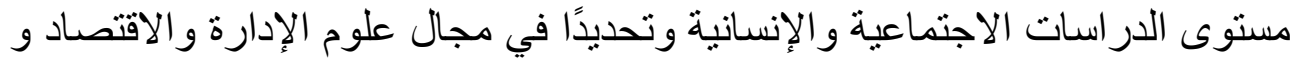




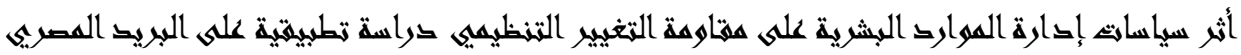

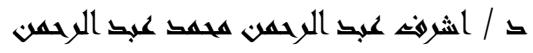

هما سياسات إدارة الموارد البشرية و ابعاد مقاومة التغيير التنظيمي و تأتي أهمية

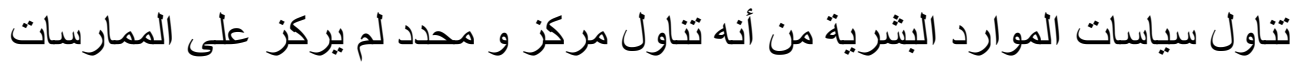

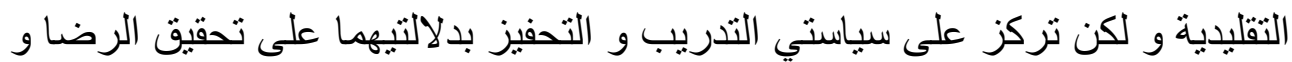

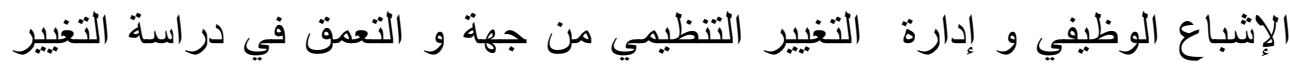
التنظيمي و أبعاده من جهة أخرى الإن.

\section{ب ـالأهمية التطبيقية}

تتبع أهمية الدر اسة التطبيقية من تركيز ها على تطبيق سياسات إدارة الموارد البشرية

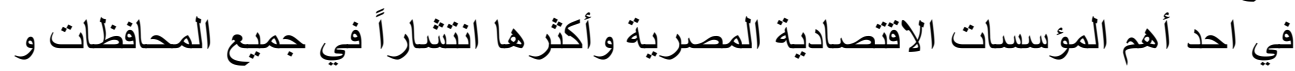

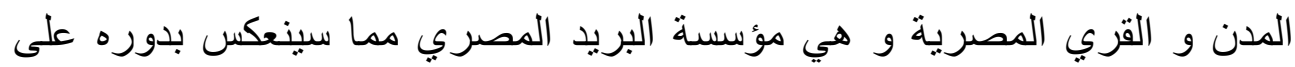

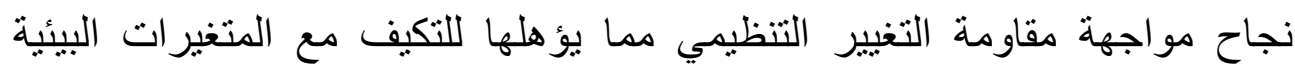

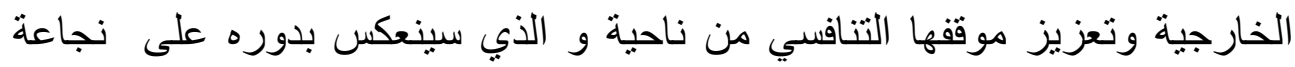
الأداء و تميز الخدمات المقدمة لملايين المو اطنين.

\section{سادساً - منهجية البحث و أسلوبه}

اعتمد الباحث على منهج در اسة الحالة من خلال التطبيق على البريد المصري. استخدم الباحث الأسلوب الوصفي التحليلي الذى يقوم على وصف دو ور تحليل الظاهرة

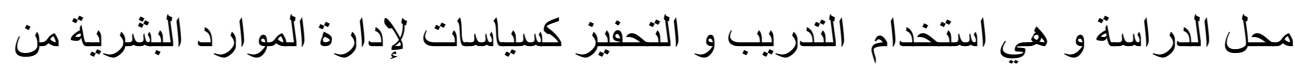

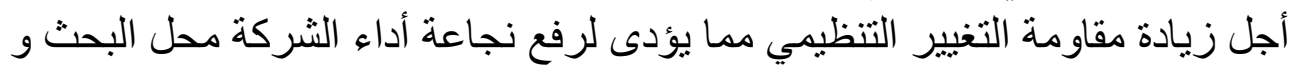
تحقيق أهدافها . استخدم الباحث برنامج: SPSS الإحصائي لتحليل البيانات. سابعاً- مجتمع و عينة البحث

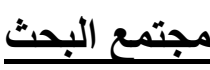

قيادات البريد المصري البيد (مدر اء القطاعات و الإدار ات و مدر اء العموم ) عينة البحث 


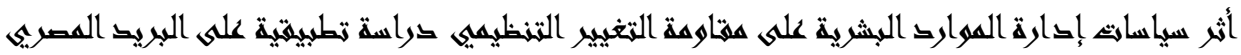

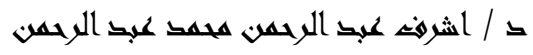

استخدم الباحث أسلوب الحصر الثامل مع مجتمع قيادات البريد المصري (ro ( ) مفردة

\section{البيانات و وسائل جمعها :-}

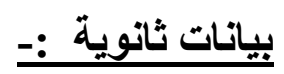

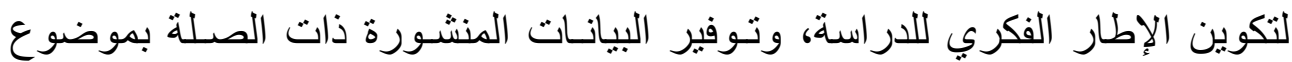

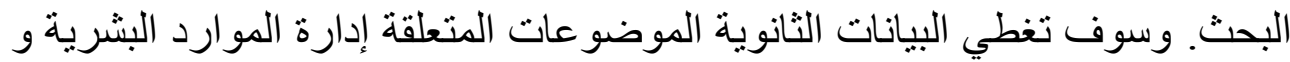

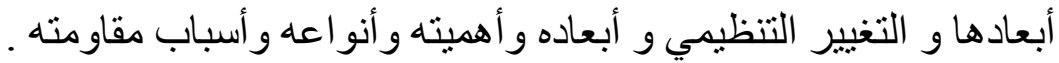

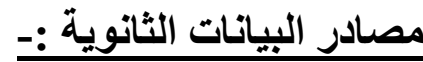

هالكتب و المراجع العربية و الأجنبية المتعلقة بإدارة الموارد البشرية و التنظيم بشكل

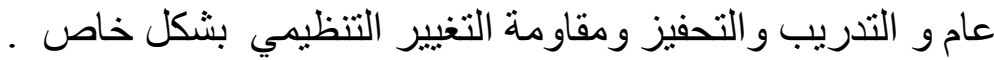
تقارير منظمات حكومية و شركات أبحاث خاصة و و تقارير المؤسسة موضع

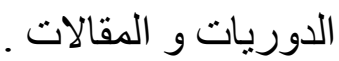

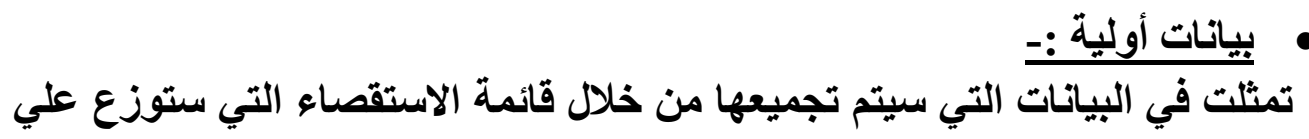

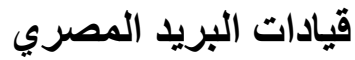
تحليل البيانات :SPSS من خلال برنامج تحليل البيانات الإحصائية ثامناً :الأساليب الإحصائية المستخدمة

اعتمد الباحث على الأساليب الإحصائية الوصفية Descriptive Statistics:

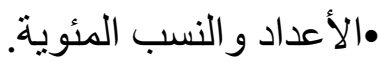

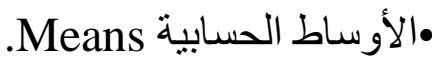
•الانحر افات المعيارية Standard Deviation. 


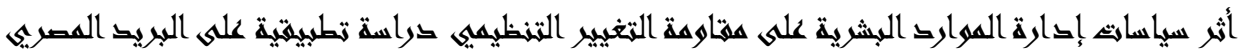

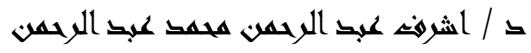

$$
\text { وذللك لعدم استخدم عينات عشو ائية بل حصر شامل و عدم الحاجة الى إجر اء }
$$
الاختبار ات الاستدلالية لتعميم النتائج.

\section{تانى عشر- حدود البحث}

حدود موضومية

اقتصر الباحث على دراسة أثز سياسات إدارة الموارد البشرية في بالبريد

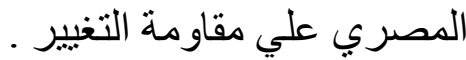

$$
\begin{aligned}
& \text { حدود تطبيقةة اختار الباحثة مؤسسة البريد المصري . } \\
& \text { جدود مكانية } \\
& \text { حدود زمانية } \\
& \text { عام • r. } \\
& \text { التحليل الإحصائي : }
\end{aligned}
$$

( ) تصميم أداة البحث:

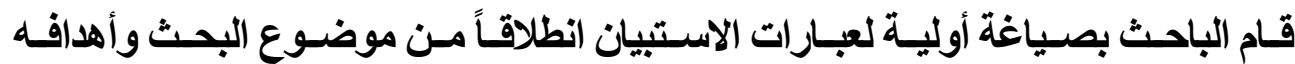
وتساؤلاته وذلك بعد القزاعة المتأنية والاطلاع على الأدبيات والدراسـات السـابقة المتعقة مونة

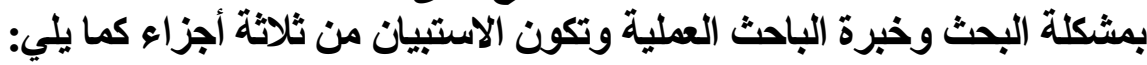
الجزء الأول: ويشمل البيانات الشخصية. الجزء الثـاني: يتضمن البنود الخاصسة بسياسـات إدارة المـوارد البشرية ويبلغ عدد

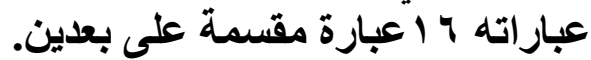

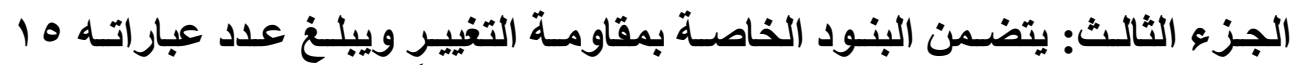

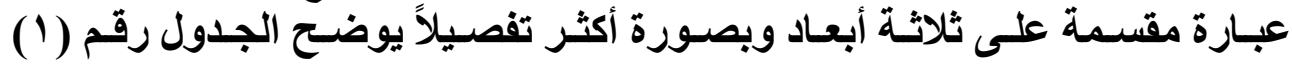




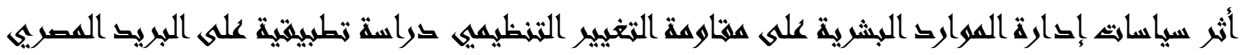

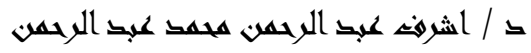

متغيرات البحث وعناصر قياسها ورموز أسئلتها التي تعكسها قائمة الاستقصاء. جدول رقم (1) متغيرات البحث وعناصر قياسها ورموز أسئلتها التي تعكس قائمة الاستقصاء

\begin{tabular}{|c|c|c|c|}
\hline عدد الاسئلة & 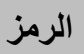 & الأبعاد & المتغيرات \\
\hline 1 من (1) & $\mathbf{X 1}$ & التدريب & \multirow{2}{*}{ سياسات إلدارة الموارد المستقلة) } \\
\hline 1 من (9-7 1 ) & $\mathbf{X} 2$ & التحفيز & \\
\hline 0 من (V & Y1 & الخوف من خسارة المركز الوظيفي & \multirow{3}{*}{ (المتغير التابع) } \\
\hline ( & Y2 & الخوف من زيادة أعباء العمل & \\
\hline ( من (r-r & Y3 & احتمال تخفيض الدخل & \\
\hline
\end{tabular}

وقد تم قياس استجابات أفراد العينة لفقرات المقياس، طبقا لمقياس ليكرث الخماسسي كما هو موضح في الجدول رقم (Y). جدول رقم (Y) درجات مقياس ليكرت

\begin{tabular}{|c|c|c|c|c|}
\hline غير موافق تمـاما & غير موافق & محايل & اوافق & او افق تمـامـا \\
\hline 1 & $r$ & $r$ & $\varepsilon$ & 0 \\
\hline
\end{tabular}

وقد تم حساب مستوي الأهمبة وفقاً للمعادلة التالية:

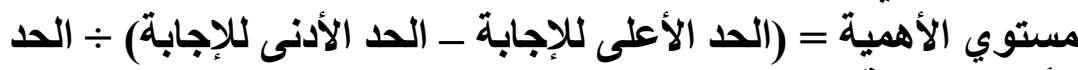
الأعلى "لإجابة الإه

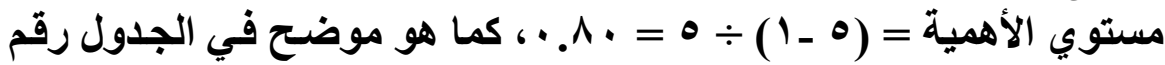




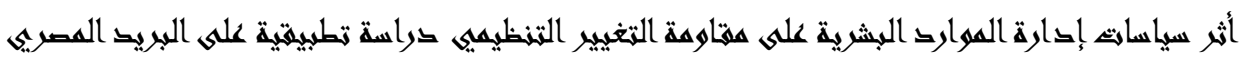

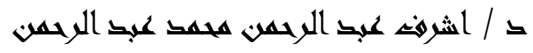

\begin{tabular}{|c|c|}
\hline مستوي الأهمية & المتوسط المرجح \\
\hline ضعيفة جدا & أقل · • \\
\hline ضعيفة & 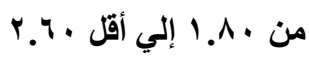 \\
\hline متوسطة & من · ج. ץ إلي أقل · ع. \\
\hline مرتفعة & 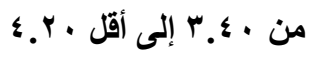 \\
\hline مرتفعة جدا & من · r. . إلى • \\
\hline
\end{tabular}

ويشمل بد وص وثباث أداة البحث أداة البحث على صدق الاتساق الظاهري وثبات وصدق الاتساق الداخلي لأداة البحث وذلك على النحو التالي:

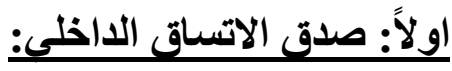
يقصد بصدق الاتساق الداخلي مدى اتساق كل عبارة من عبار ات الاستبيان مع البعد الذي تتتمي إلبه هذه العبارة، وقد قام الباحث بحساب الاتساق الداخلي للاستبيان وذلك من خلال حساب معاملات الارتباط بين كل عبارة من عبار ات أبعاد الاستبيان و الدرجة الكلية للبعد نفسه.

\section{ا - نتائج الاتشساق الداخلي}

يتم حساب صدق الاتساق الداخلي للاستبيان من خلال حساب معاملات الارثباط بين كل عبارة من عبارات أبعاد الاستبيان و الدرجة الكلية للبعد نفسه و ذلك لتوضيح مدى اتساق كل عبارة من عبار ات الاستبيان مع البعد الذي تتنمي إلبه هذه العبارة و ذلك علي العينة الاستطلاعية ن= - . . 


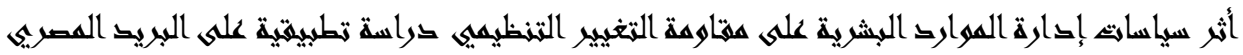

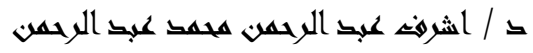

\section{وكانت النتائج كالتالى:}

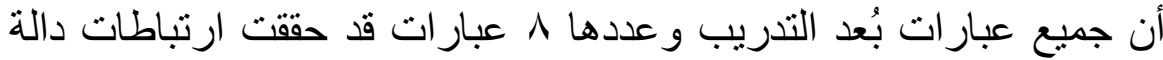

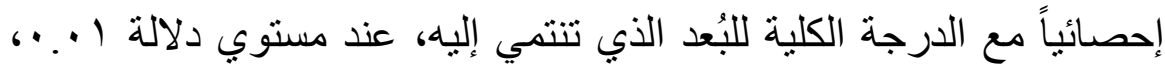

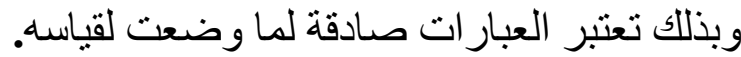

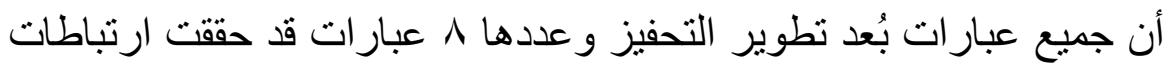

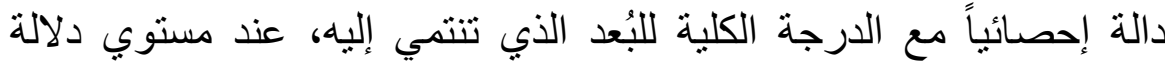

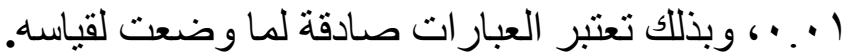

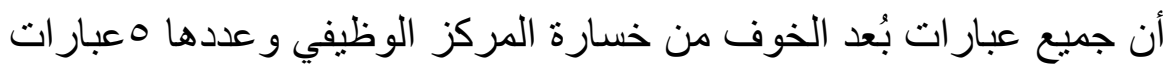

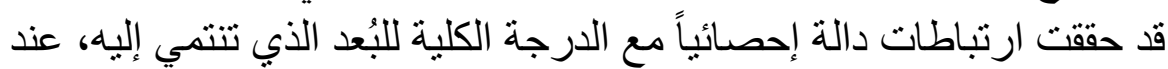

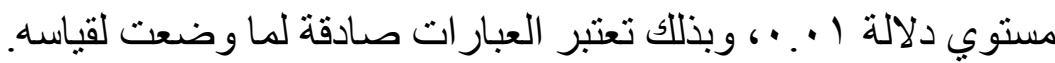

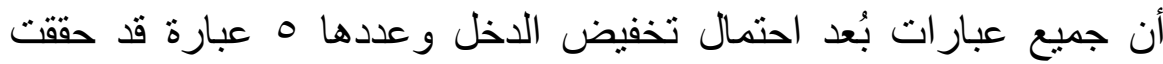

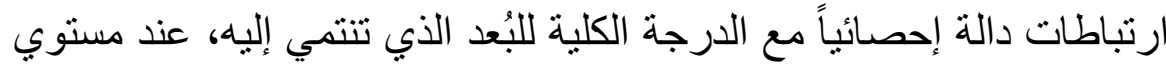

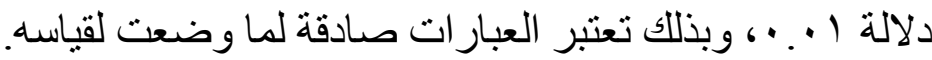

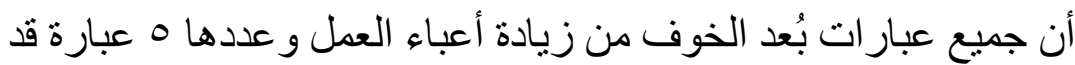

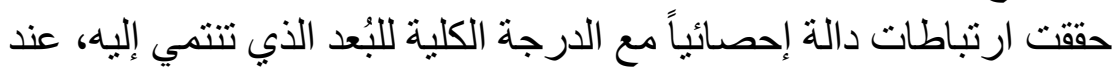

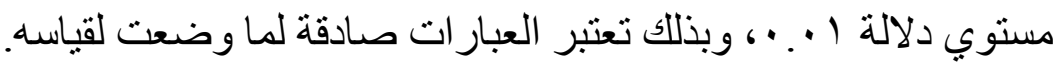

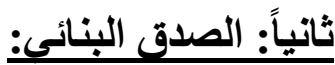
يعتبر الصدق البنائي أحد مقاييس صدق الأئن الأداة الذي يقيس مدى تحقق الأهداف التي

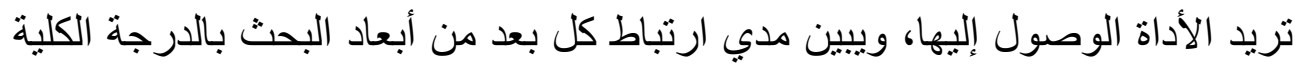
لعبار ات الأبعاد. من خلال قياس معامل ارتباط كل بعد من أبعاد الاستبيان بمجموع الدرجة الكلية في

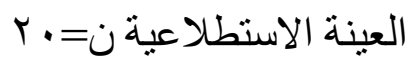

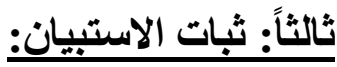
يقصد بثبات الاستبيان أن يعطي هذا الاستبيان نفس النتيجة لو تم إعادة توزيعه أكثر من مرة تحت نفس الظروف والثروط، أو بعبارة أخرى أن ثبات الاستبيان يعني 


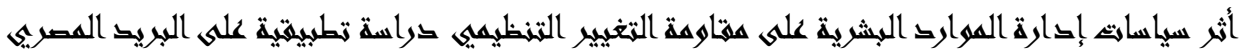

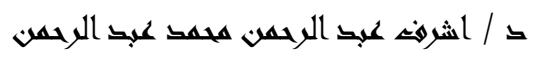

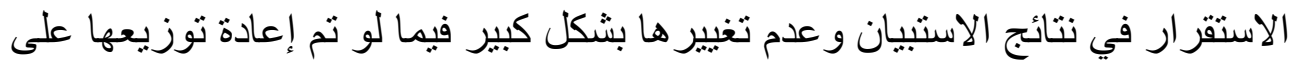

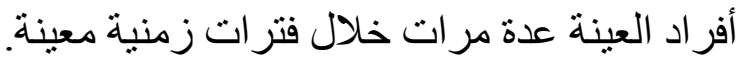
تحقق الباحث من ثبات استبيان البحث من خلاثل طرينة فيقتين وهما طريقة التجزئة النصفية ومعامل ألفا كرونباخ.

\section{أولاً: طريقة التجزئة النصفية: Split-Half Coefficient method}

تم استخدام درجات العينة الاستطلاعية لحساب ثبات الاستبيان بطريقة التجزئة

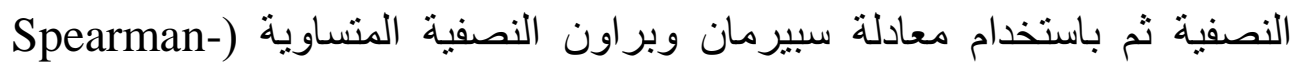
Brown Coefficient و و أكدت النتائج أن معاملات الارتباط (Guttman Split-Half Coefficient)

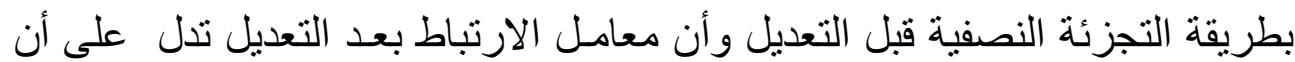

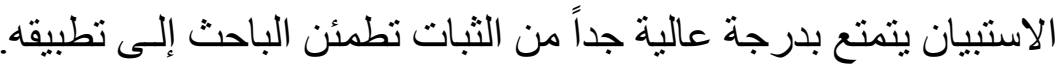

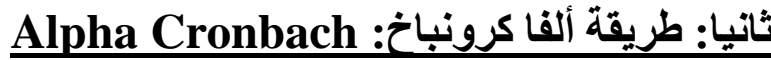

استخدم الباحث طريقة أخري من طرق حساب الثبات وهي طريقة ألفا كرو نباخ، وذلك بغرض التحقق من ثبات أداة البحث، "ويعتمد ألفا كرونباخ على هن حساب تباينات

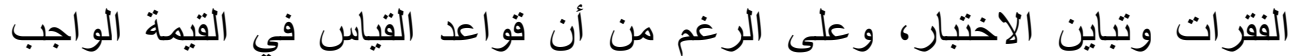
الحصول عليها غير محددة، إلا أن الحصول على (Alpha > 0.67) يعتبر معقو لا.

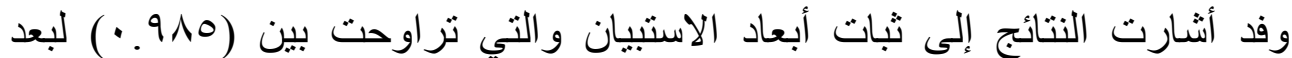

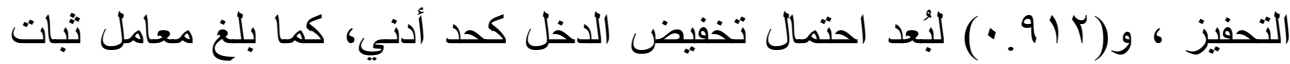

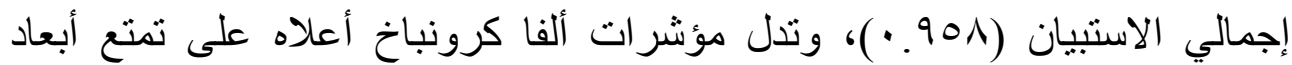

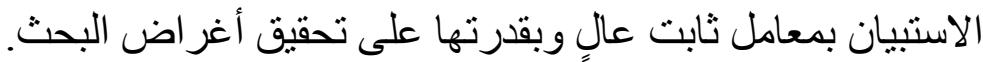




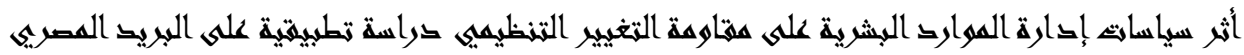

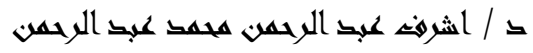

( ) متائج الاراسة الميدانية

تم التوصل لنتائج الدراسة الميدانية النانية باستخدام:

•المتوسطات الحسابية والانحر افات المعيارية و المتوسط المئوي المرجح في نتائج

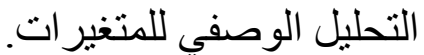

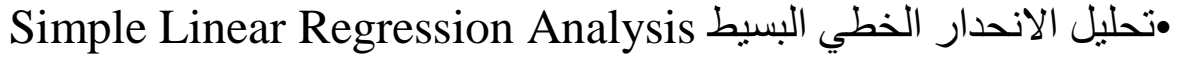
لمعرفة أثر (المتغير المستقل) على كل بُعد من أبعاد (المتغير التابع).

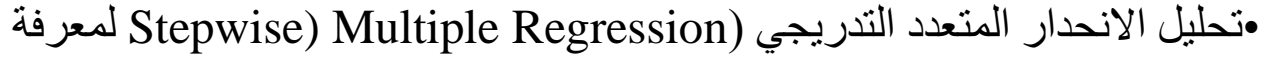
أثثر أبعاد (المتغير المستقل) على (المتغير التابع).

\section{ا-نتائج الإحصاء الوصفي لمتغيرات البحث} جدول رقم (؛) المتوسطات والاتحر افات المعيارية واستجابات عينة البحث نحو البحو

$$
\text { أبعاد البحث ن = Tro }
$$

\begin{tabular}{|c|c|c|c|c|}
\hline مستوي الأهمية & المرجح المئوي & المعياري & المتوسط & البعد \\
\hline مرتفعة جداً & $\Lambda V$ & , Vro & $\varepsilon$, ro $^{\circ}$ & X1 التدريب X1 \\
\hline مرتفعة جداً & 90 & $.9 \mathrm{TV}$ & \&.Vo & X2 التحفيز \\
\hline مرتفعة & vo & $.9 \leq 9$ & r.vo & الوظيفي Y1 الخوف من خسارة المركز \\
\hline مرتفعة & Ar. 1 & 0.924 & $£ .100$ & Y2 احتمّال تخفيض اللخل Y2 \\
\hline مرتفعة جدا & $\left.\wedge \Lambda_{.}\right) \leqslant$ &..$A Y T$ & $\varepsilon . V_{V}$ & Y3 الخوف من زيادة أعباء العمل \\
\hline مرتفعة جدا & 85.65 & 0.832 & 4.28 & 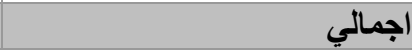 \\
\hline
\end{tabular}

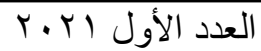




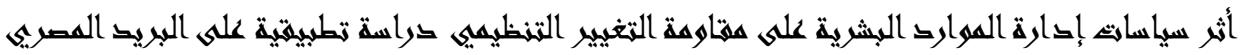

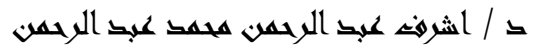

يُظهر الجدول السابق رقم (؛ ) المتوسطات الحسابية والانحر افات المعيارية لاستجابات عينة البحث تجاه عبارات أبعاد الاستبيان ، وتثثير الدرجة الاندية الكلية الواردة

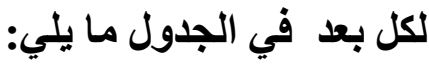

درجة بُعد التدريب لعينة البحث (مرتفعة جداً)، حيث بلغ المتوسط الحسابي للارجة

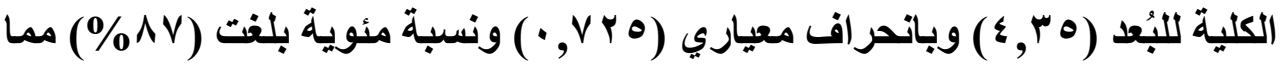
يال على انخفاض التثتت في آراء عينة البحث وتثارب الآراء تجاه البحاه البعد.

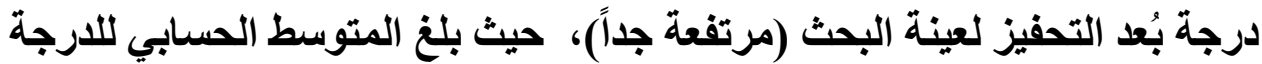

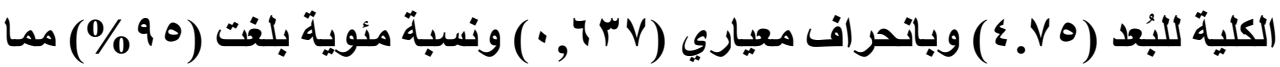
يدل على انخفاض التثتت في آراء عينة البحث وتقارب الآراء تجاه البعد.

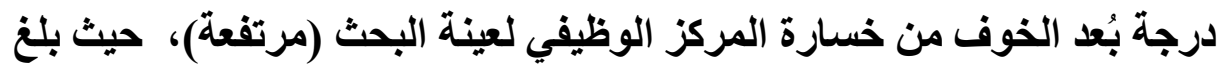

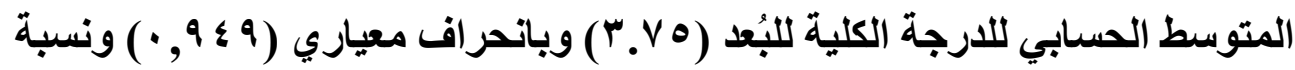

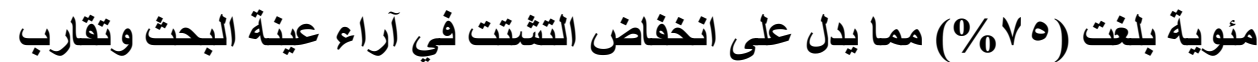

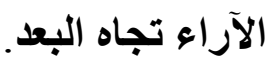

درجة بُعد الخوف من احتمال تخفيض الاخل لعينة البحث (مرتفعة)، حيث بلغ (ابلغ

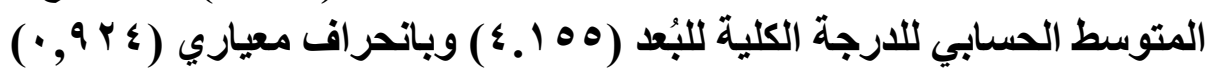

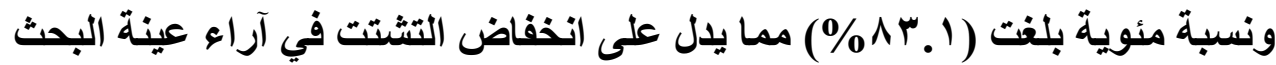

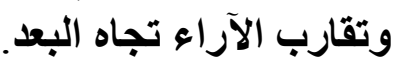

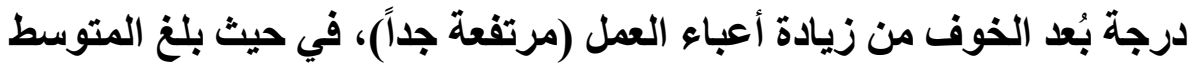

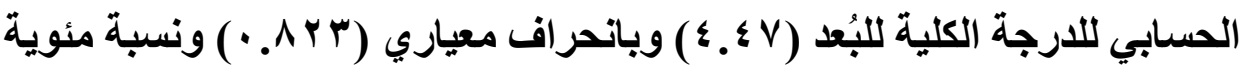

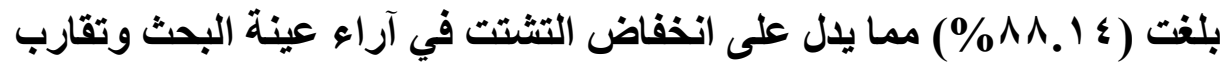
الآراء تجاه البعد . 


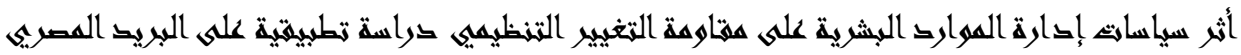

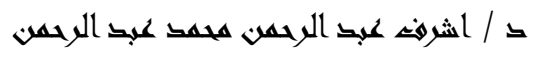

يلاحظ أن درجة أبعاد التدريب والتحفيز والخوف من زيادة أعباء العمل مرتفعة جداً

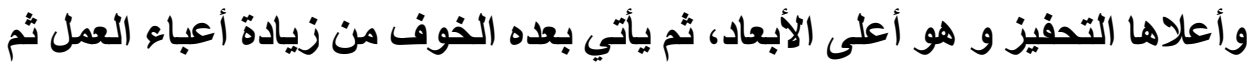
التدريب.

يلاحظ أن درجة ابعاد الخوف من خسارة المركز الوظيفي واحتمال تخفيض الاخل مرتفعة، وأن بعد الخوف من خسارة المركز الوظيفي هو الأقل على الإطلاق. يلاحظ أن إجمالي ابعاد الاستبيان مرتفعة جداً حيث بلغ المتوسط الحسابي للارجة

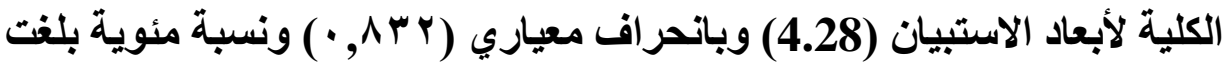

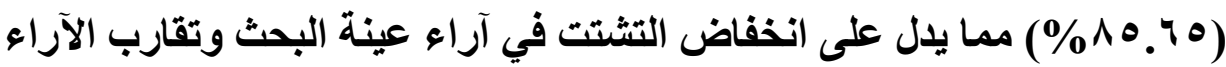
تجاه كل الأبعاد.

Y بانتائج اختبار فروض البحث

قام الباحث باختبار الفرضيات وعرض علاقات الارتباط والتأثير وتحليلها كما يلي الفرض الرئيس

"توجد علاقة إيجابية ذات دلالة إحصائية بين تطبيق سياسات إدارة الموارد البشرية

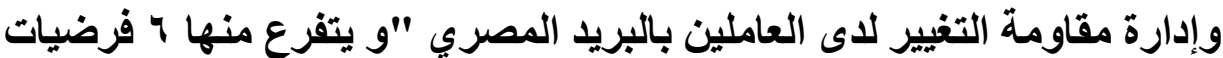

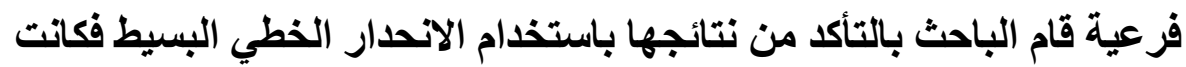
كالتالي: 


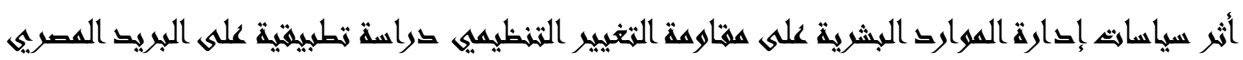

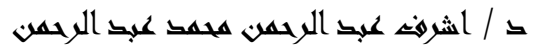

الجدول (0) نتائج المؤشرات التي توضح العلاقة والتأثير بين متغيرات البحث

\begin{tabular}{|c|c|c|c|c|c|c|c|c|c|}
\hline 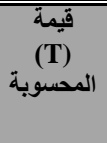 & $\begin{array}{l}\text { الانحار } \\
\text { Bعل } \\
\text { B }\end{array}$ & درجات الحرية & المسيمة (F) & $\begin{array}{c}\text { التحديد } \\
\text { Rع }^{2}\end{array}$ & $\begin{array}{c}\text { الارتباط } \\
\text { R } \\
\text { المامل }\end{array}$ & المتفير التابع & & المستقلّ & \\
\hline$\cdot, \cdot 1 \varepsilon$ & 0.471 & الانحدار & 16.35 & 0.497 & 0.705 & الخركز الوظيفي من خسارة & \multirow{6}{*}{ 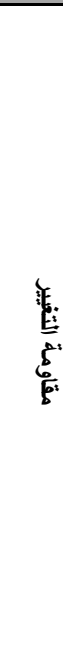 } & \multirow[t]{3}{*}{ النكريب } & \multirow{6}{*}{ : } \\
\hline$\cdot, \cdot 11$ & 0.462 & & 11.5 & 0. ros & 0.596 & |احتمال تخفيض & & & \\
\hline$\cdot, \cdot Y V$ & 0.452 & البو اقي \& 1 T & 8.45 & 0.672 & 0.82 & |أعباء العمل من زيادة & & & \\
\hline$\cdot, \cdot Y Y$ & 0.523 & & 9.5 & 0.32 & 0.517 & |المركز الوظيفي من خسارة & & \multirow[t]{3}{*}{ التحفيز } & \\
\hline$\cdot, .19$ & 0.54 & المجموع Y T ا & 13.27 & 0.29 & 0.572 & الدخل احتل تخفيض & & & \\
\hline$\cdot, \cdot 17$ & 0.662 & & 6.5 & $\cdot . \wedge 1$ & 0.9 & |أعباء العمل زيادة & & & \\
\hline$\cdot, \cdot 14$ &.$r{ }^{4} \theta$ & & 10.29 & $\cdot . \$ 91$ & 0.685 & $\mathbf{Y}$ & الكلي & $\mathbf{X}$ & الكلي \\
\hline
\end{tabular}

الفرضية الفرعية الأولىي

توجد علاقة إيجابية ذات دلالة إحصائية بين التدريب كبعد من أبعاد إدارة الموارد

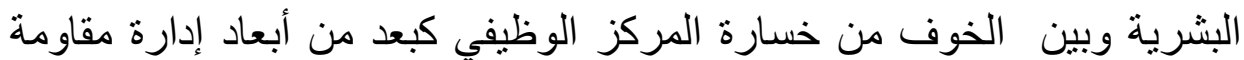

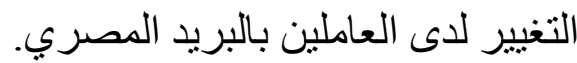

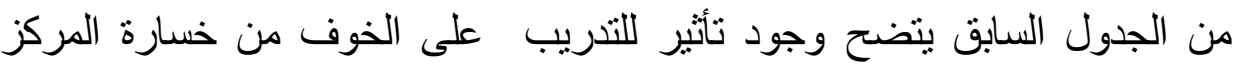

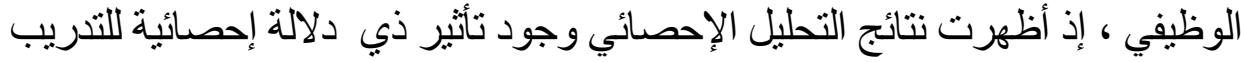

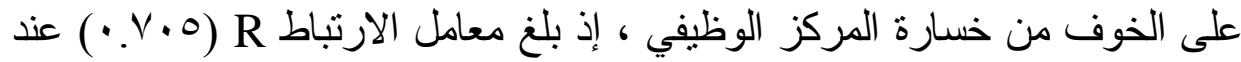




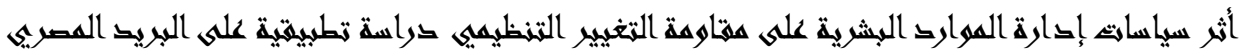

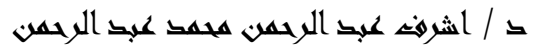

مستوي معنوية ه.. •، أما معامل التحديد R

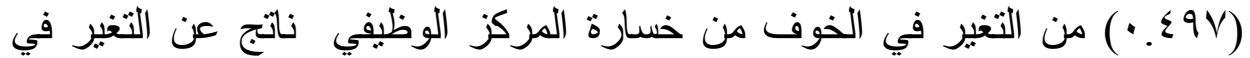

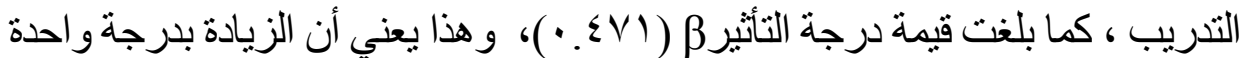

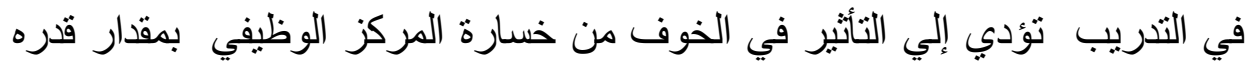

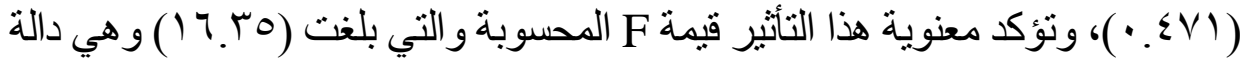

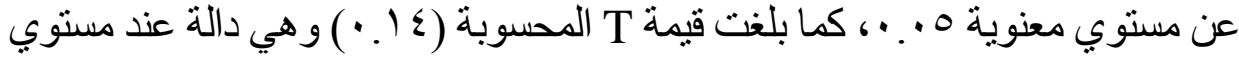
معنوية 0 •. •، ومما سبق يتضح لنا تحقق الفرضية الفرعية الأولى التي تتص على علي أنه توجد علاقة إيجابية ذات دلالة إحصائية بين التدريب كبعد من أبعاد إدارة الموارد

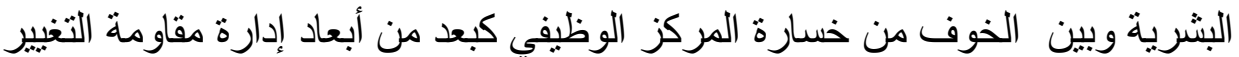
لاى العاملين بالبريد المصرين

\section{الفرضية الفرعية الثانية}

توجد علاقة إيجابية ذات دلالة إحصائية بين التحفيز كبعد من أبعاد إدارة الموارد

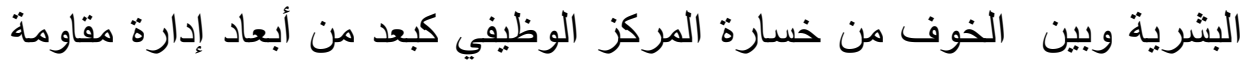
التغيير لدى العاملين بالبريد المصري.

من الجدول السابق يتضح وجود تأثثر للتحفيز على الخوف من خسارة المركز

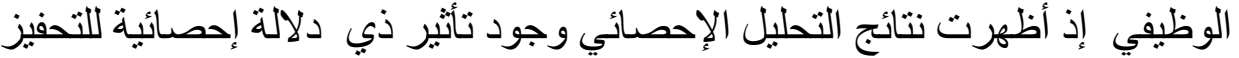

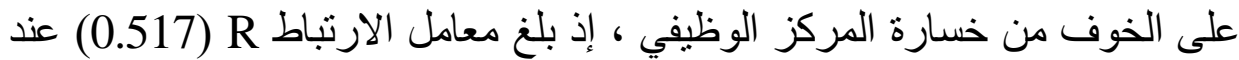

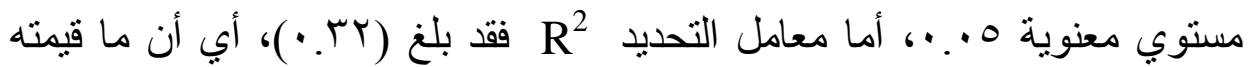

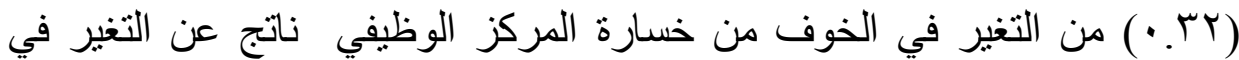

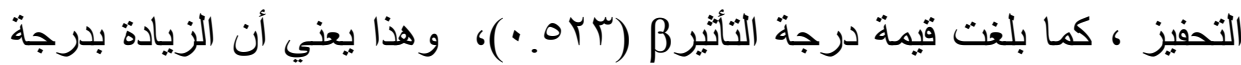
واحدة في التحفيز ، تؤدي إلي التأثير في الخوف من خسارة المركز الوظيفي بمقدار

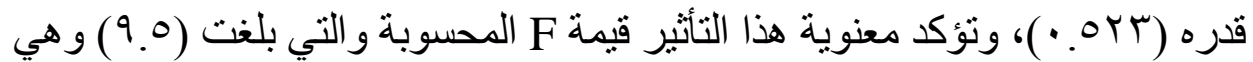

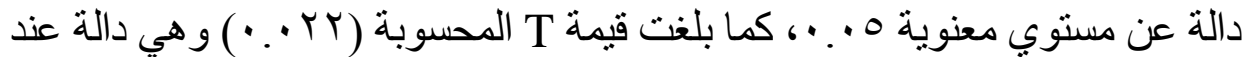




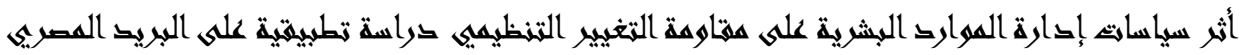

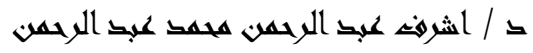

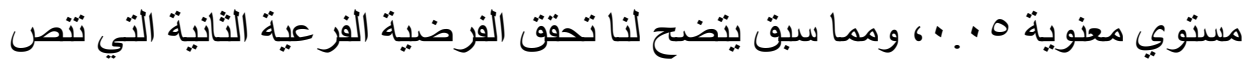
علي أنه توجد علاقة إيجابية ذات دلالة إحصائية بين التحفيز كبعد من أبعاد إدارة

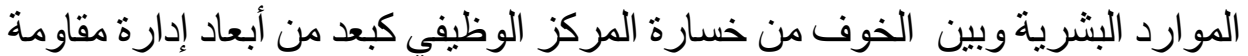
التغيير لدى العاملين بالبريد المصريني.

\section{الفرضية الفرعية الثالثة}

توجد علاقة إيجابية ذات دلالة إحصائية بين التدريب كبعد من أبعاد إدارة الموارد

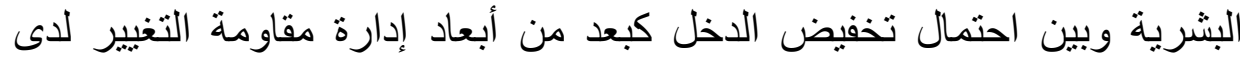

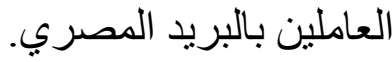

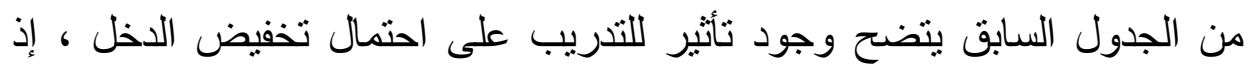

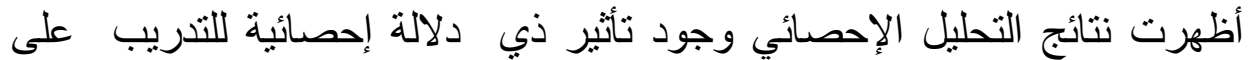

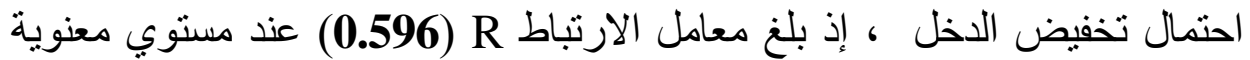

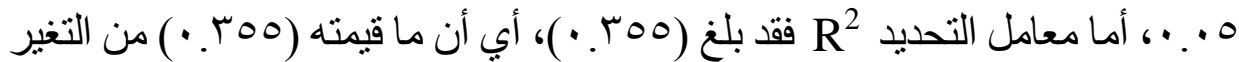

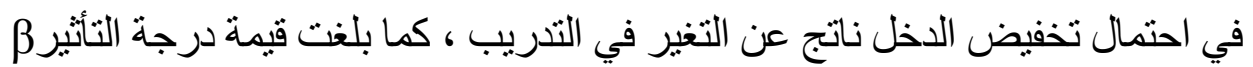

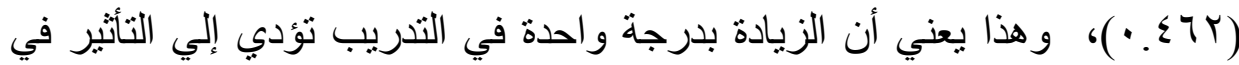

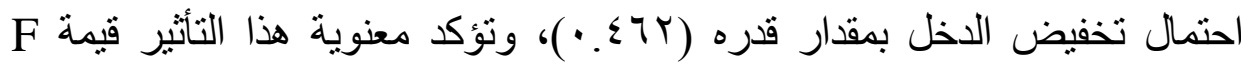

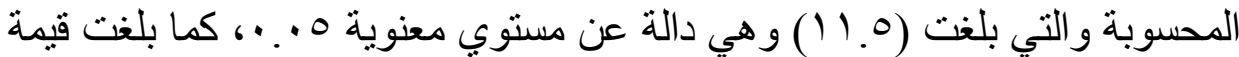

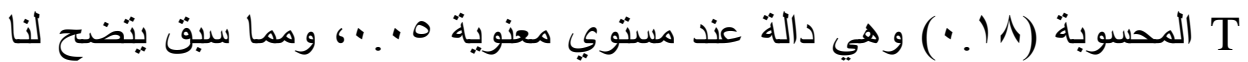

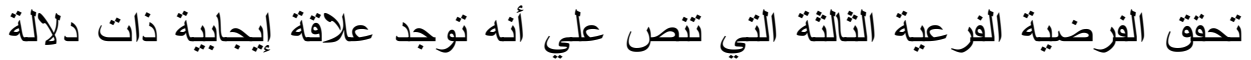

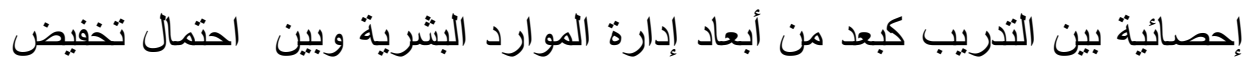

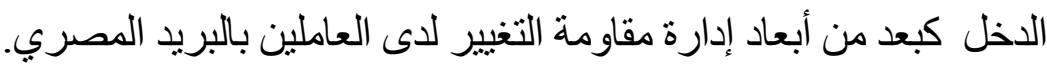

\section{الفرضية الفرعية الرابعة:}

توجد علاقة إيجابية ذات دلالة إحصائية بين التحفيز كبعد من أبعاد إدارة الموارد

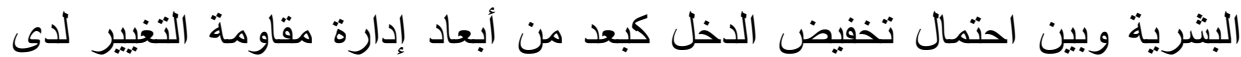




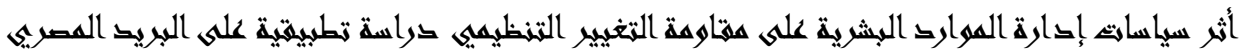

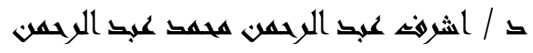

العاملين بالبريد المصري.

من الجدول السابق يتضح وجود تأثير للتحفيز على احتمال تخفيض الدخل ، إذ أظهرت

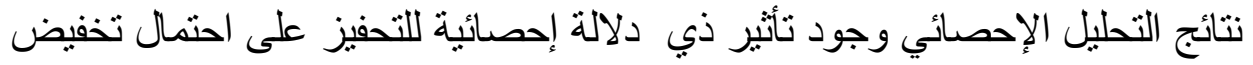

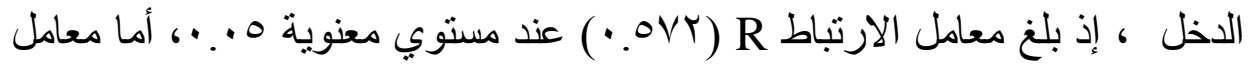

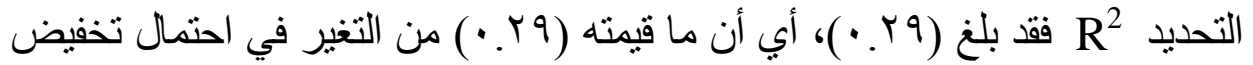

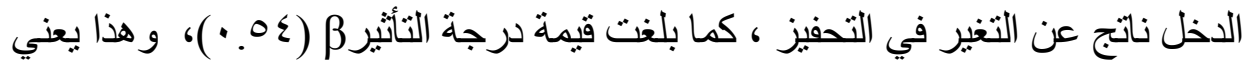

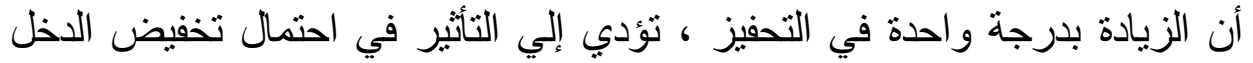

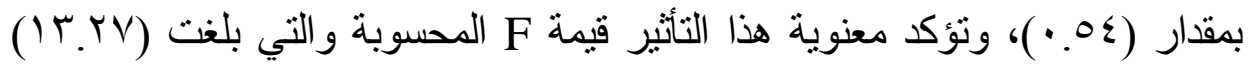

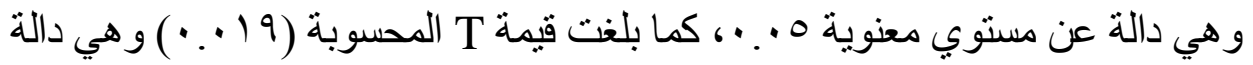

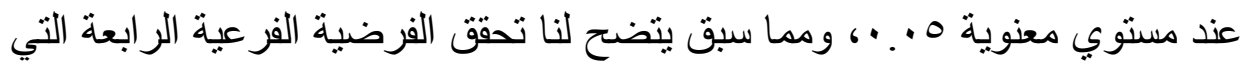
تتص علي أنه نوجد علاقة إيجابية ذات دلالة إحصائية بين التحفيز كبعد من أبعاد إدارة

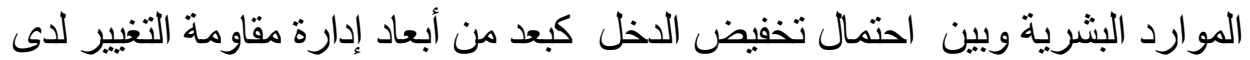
العاملين بالبريد المصري.

\section{الفرضية الفرعية الخامسة}

توجد علاقة إيجابية ذات دلالة إحصائية بين التدريب كبعد من أبعاد إدارة الموارد

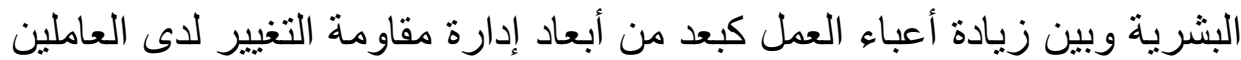

$$
\text { بالبريد المصري. }
$$

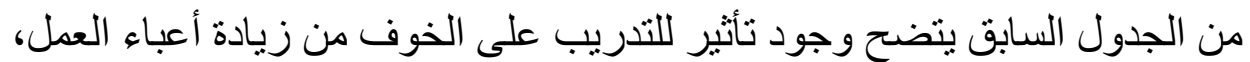

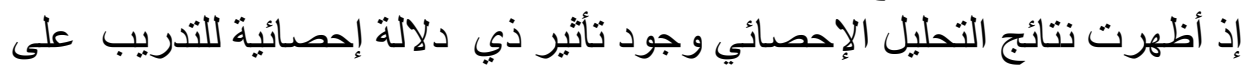

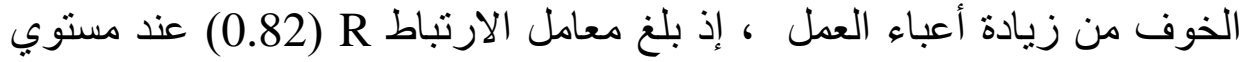

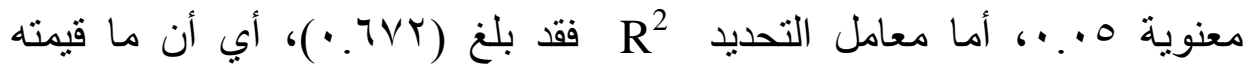

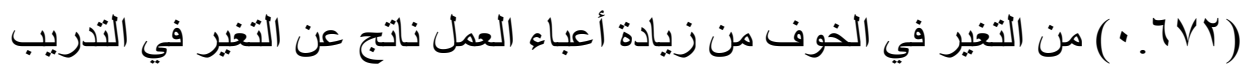

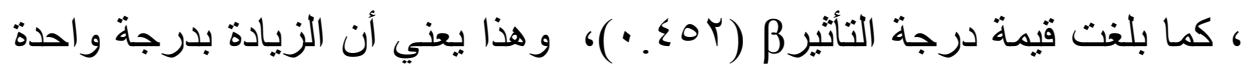




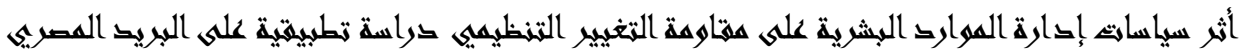

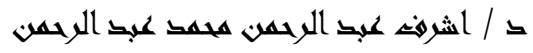

في التدريب ، تؤدي إلي التأثثر في الخوف من زيادة أعباء العمل بمقدار

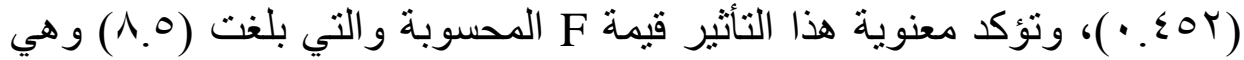

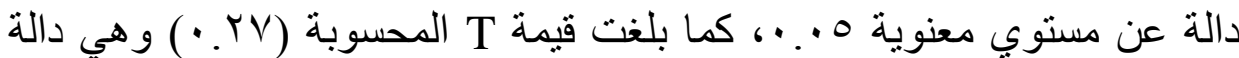

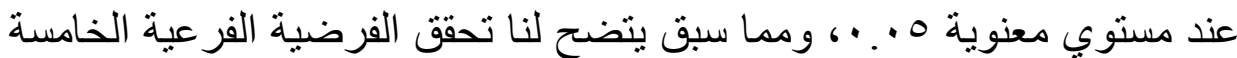

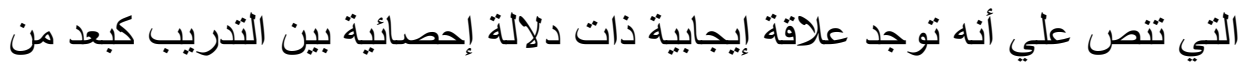

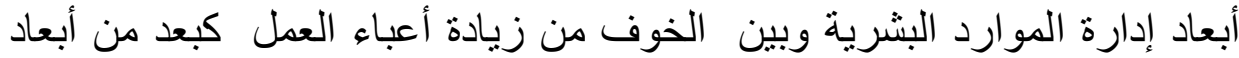

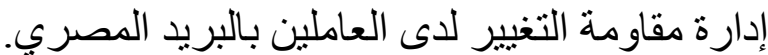

\section{الفرضية الفرعية السادسة}

توجد علاقة إيجابية ذات دلالة إحصائية بين التحفيز كبعد من أبعاد إدارة الموارد

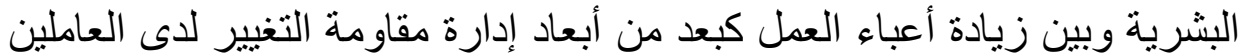
بالبريد المصري.

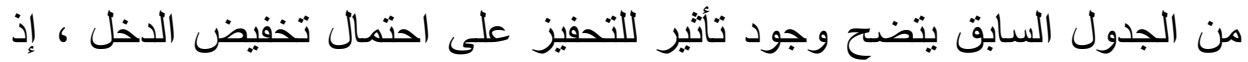

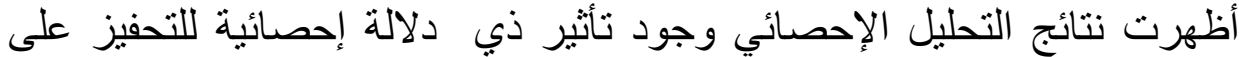

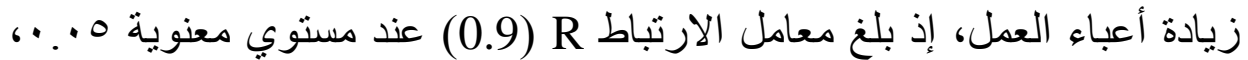

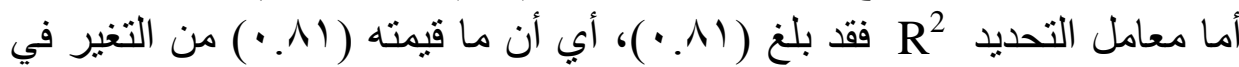

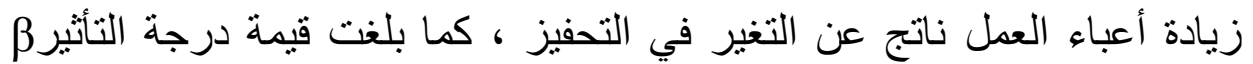

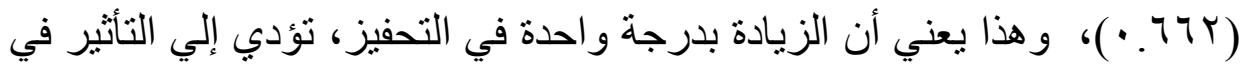

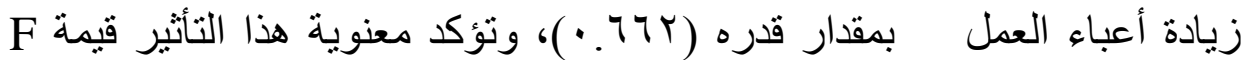

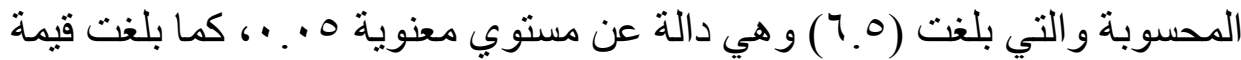

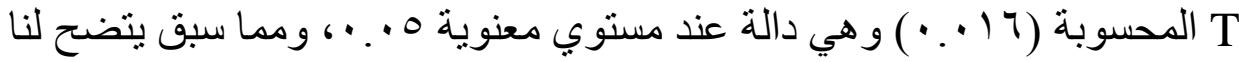
تحقق الفرضية الفرعية السادسة التي تتص علي أنه توجد علاقة إيجابية ذات دلالة النة

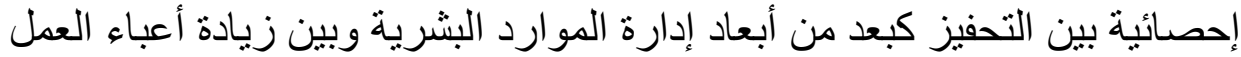
كبعد من أبعاد إدارة مقاومة التغيير لإى العاملين بالبريد المصرئ الدري. ومما سبق يتضح لنا تحقق الفرضية الرئيسة التي تتص على أنه: 


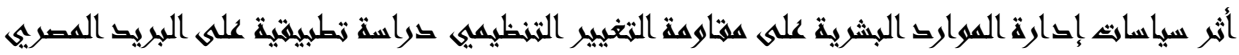

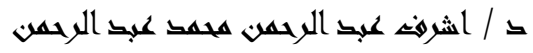

"توجد علاقة إيجابية ذات دلالة إحصائية بين تطبيق سياسات إدارة الموارد

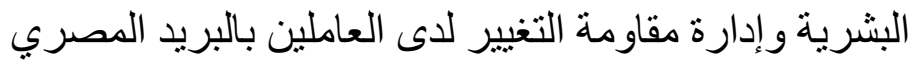

النتائج و التوصبيات

من نتائج التحليل الاحصائي للاراسة الميدانية يتضح لنا تحقق "توجد علاقة

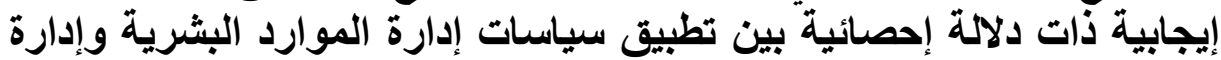

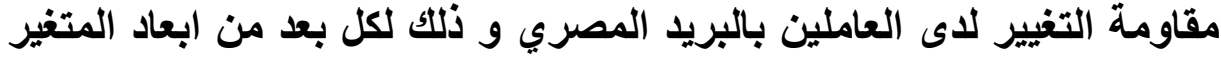

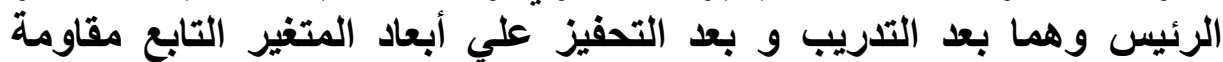
التغيير التنظيمي الثثلاثة و إن كان تأثثير التحفيز أكثر نسبياً من تأثير التدريب.

التوصيات

استمرار ادارة الموارد البشرية في مواجهة مقاومة التغيير التظظيمي

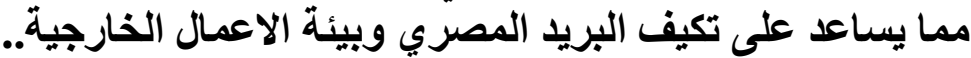

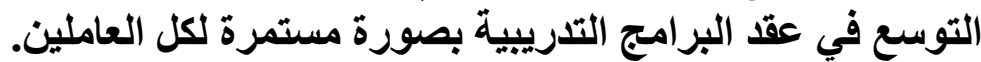

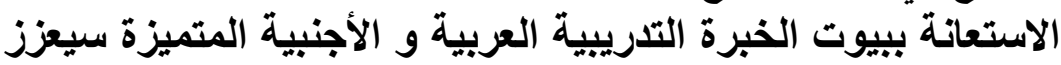
من كفاءة عملية التدريب. زيادة اشرالك العاملين في النواحي الإدارية مما يحقى قدر كبير من

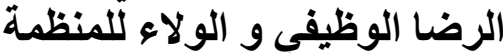
تحقيق العدالة في التحفيز المادي وربطه بالأداء سبقلّل بنسبة كبيرة من الصراع التنظيمي

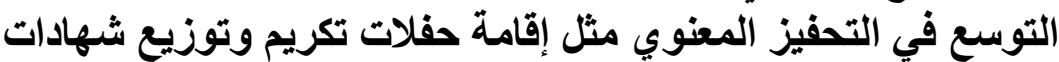

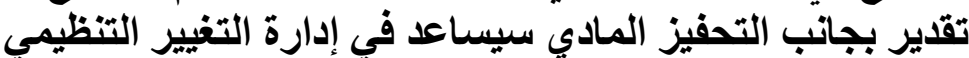

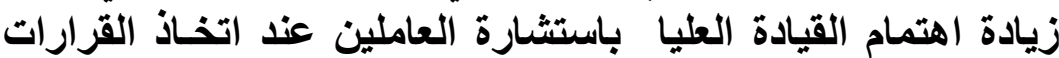

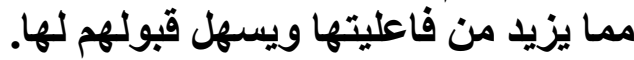




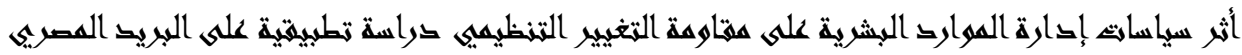

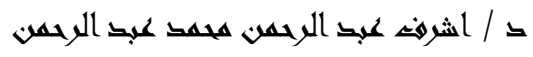

استمارة استقصاء

\section{اخي الفاضل / اختي الفاضلة \\ موظفي البريد المصري ، المحترمين}

السلام عليكم ورحمة الله وبركاته

يسعدني ويشرفني مشاركتكم القيمة في تعبئة عبار ات الاستبيان الموضوع وبين ولين أيديكم بعنوان

" أثر سياسات إدارة الموارد البشرية على مقاومة التغيير التنظيمي در اسة تطبيقية على البريد المصري"، حيث أن حضر اتكم الفئة المستهدفة.

نرجو من حضر اتكم بأبداء الر أي بما يعبر عن وجهة نظركم بكل موضو عية وشفافية علماً بأنه يتم جمع تلاك البيانات لُأغر اض البح البحث العلمي فقط وسوف تعامل من قبلنا بسرية تامة. بأنه وتفضلوا بقبول فائق الاحترام والتقدير،،،

د/ أشرف عبد الرحمن

$$
\text { هاتف : بريد الكثرونى: }
$$

العدد الأول Ir.r المجلد الثاني عشر 


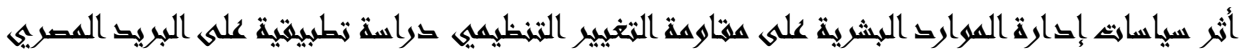

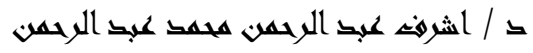

أولاًا: البيانات الشخصية

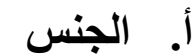

o

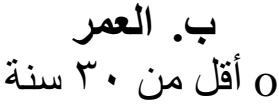

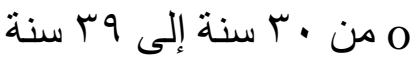

( إلى 0

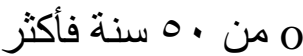

ث. المؤهل العلمي:

O بدون

O دبلوم متوسط

o

o ليسانس

o ماجستير

o دكتور اه

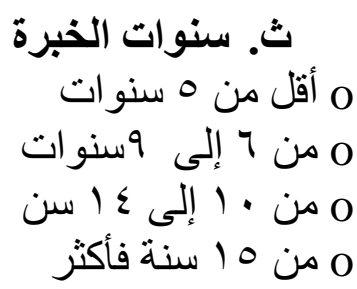

المستوى الوظيفي

Oمدير إدارة

مدير قطاع مدير إن

مدير عام

العدد الأول Ir.r

المجلد الثاني عشر 


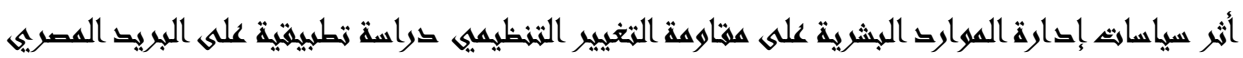

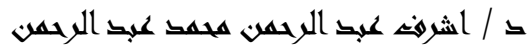

ثانياً: محاور الاستثيان

الرجاء التفضل بوضع علامة ( ل ) أمام الاختيار الذي ترونه يتوافق مع وجهة نظرك

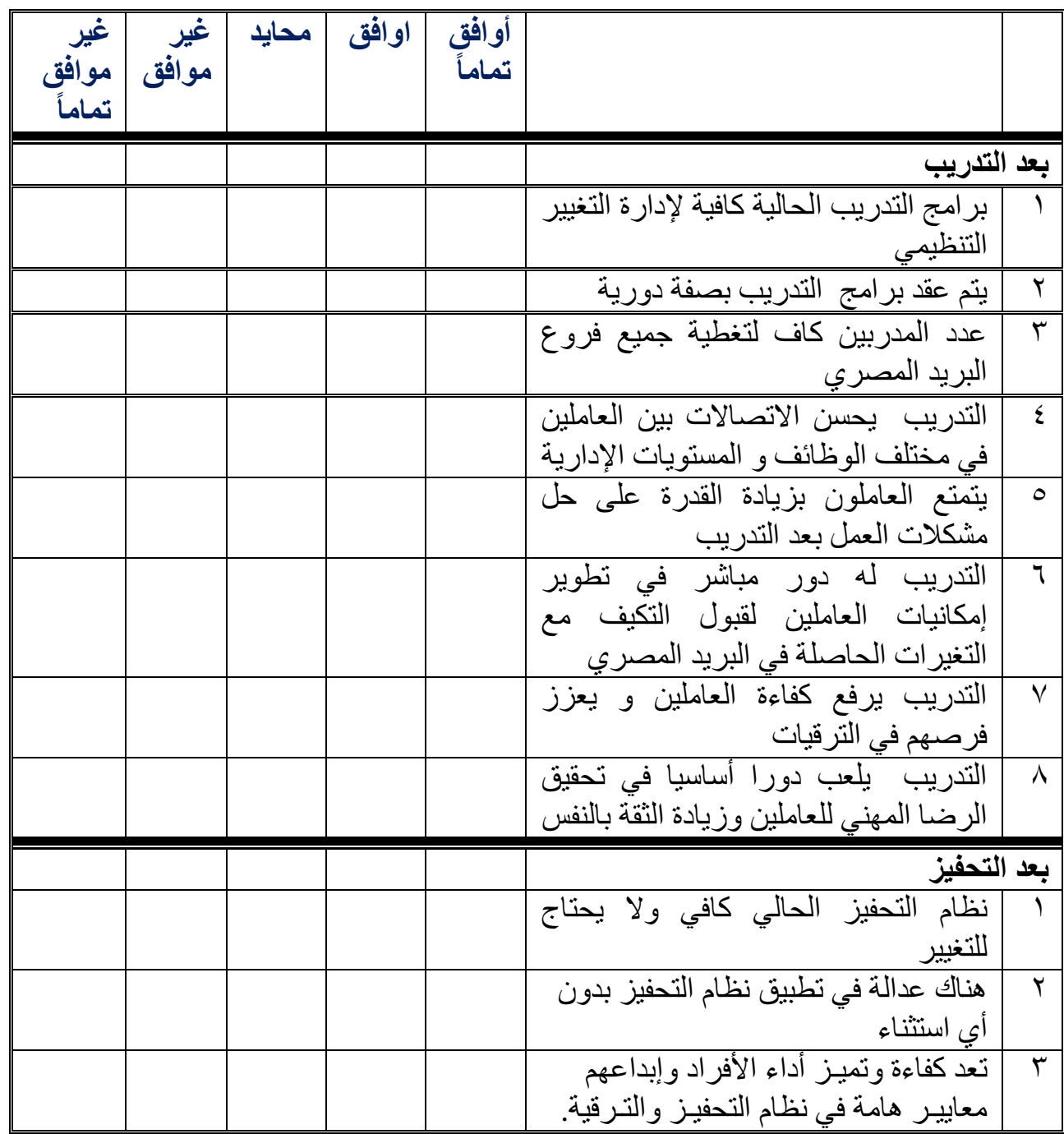

العدد الأول Ir.r

المجلد الثاني عشر 


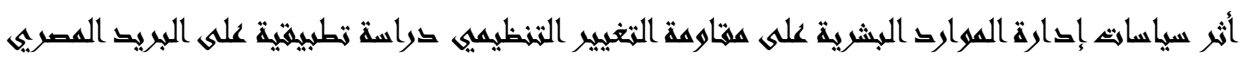

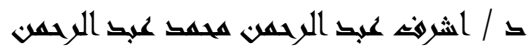

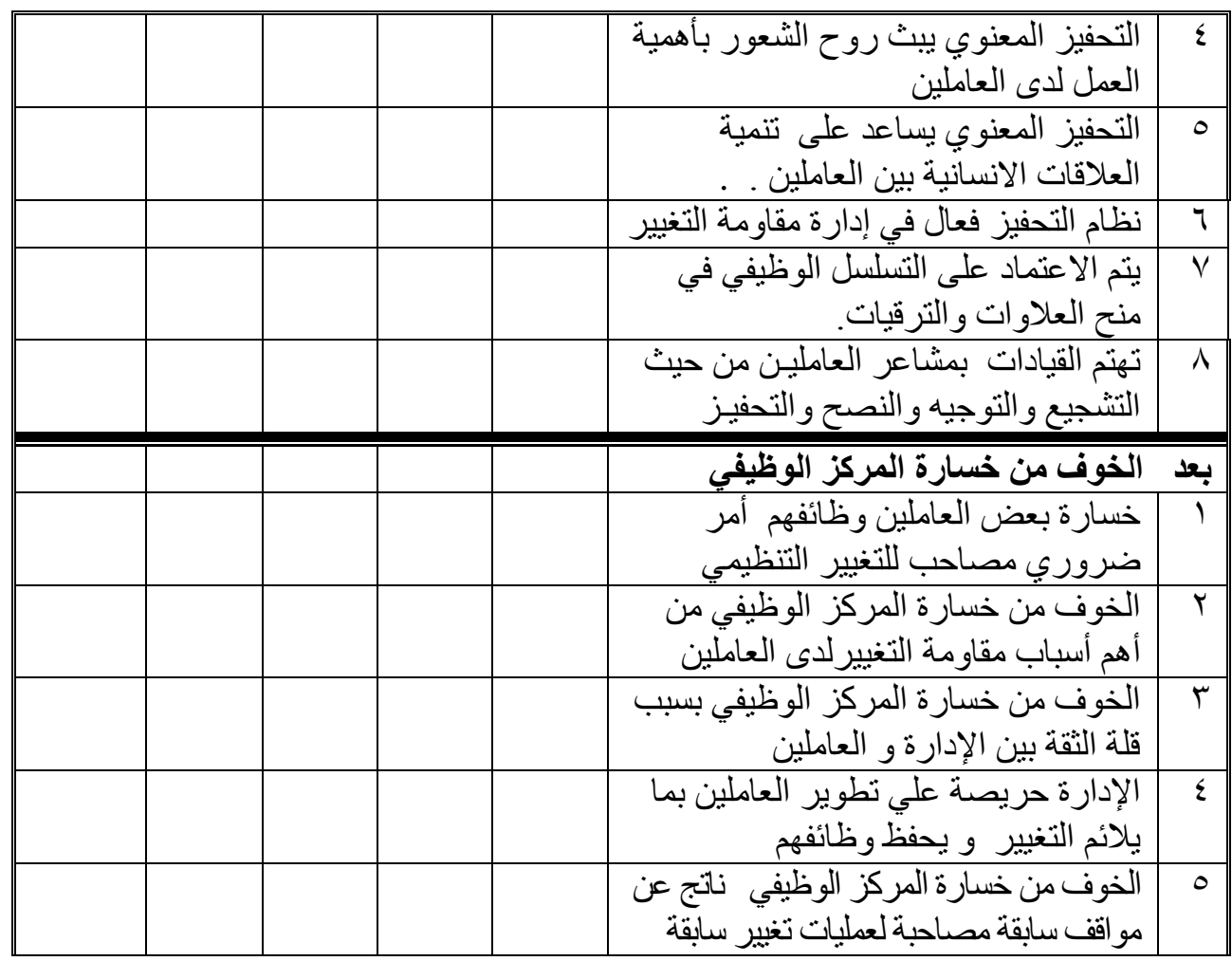

\begin{tabular}{|c|c|c|c|c|c|c|}
\hline غير & غيزر & محايل & اوافق & تماماً & & \\
\hline & & & & & \multicolumn{2}{|c|}{ بعد زيادة أعباء العمل } \\
\hline & & & & & أسباب مقاو من زيادة التغيير أعباء العمل من أهم & 1 \\
\hline & & & & & 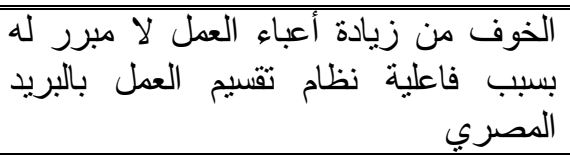 & $\bar{r}$ \\
\hline & & & & & الألدريب يرفع كفاءة و سرعة إنجاز & $\bar{\Gamma}$ \\
\hline
\end{tabular}

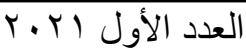
المجلد الثاني عشر 


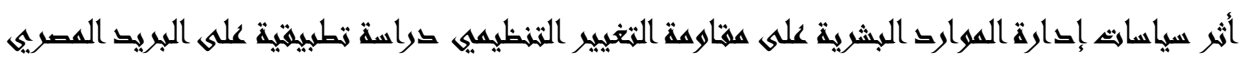

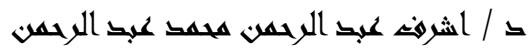

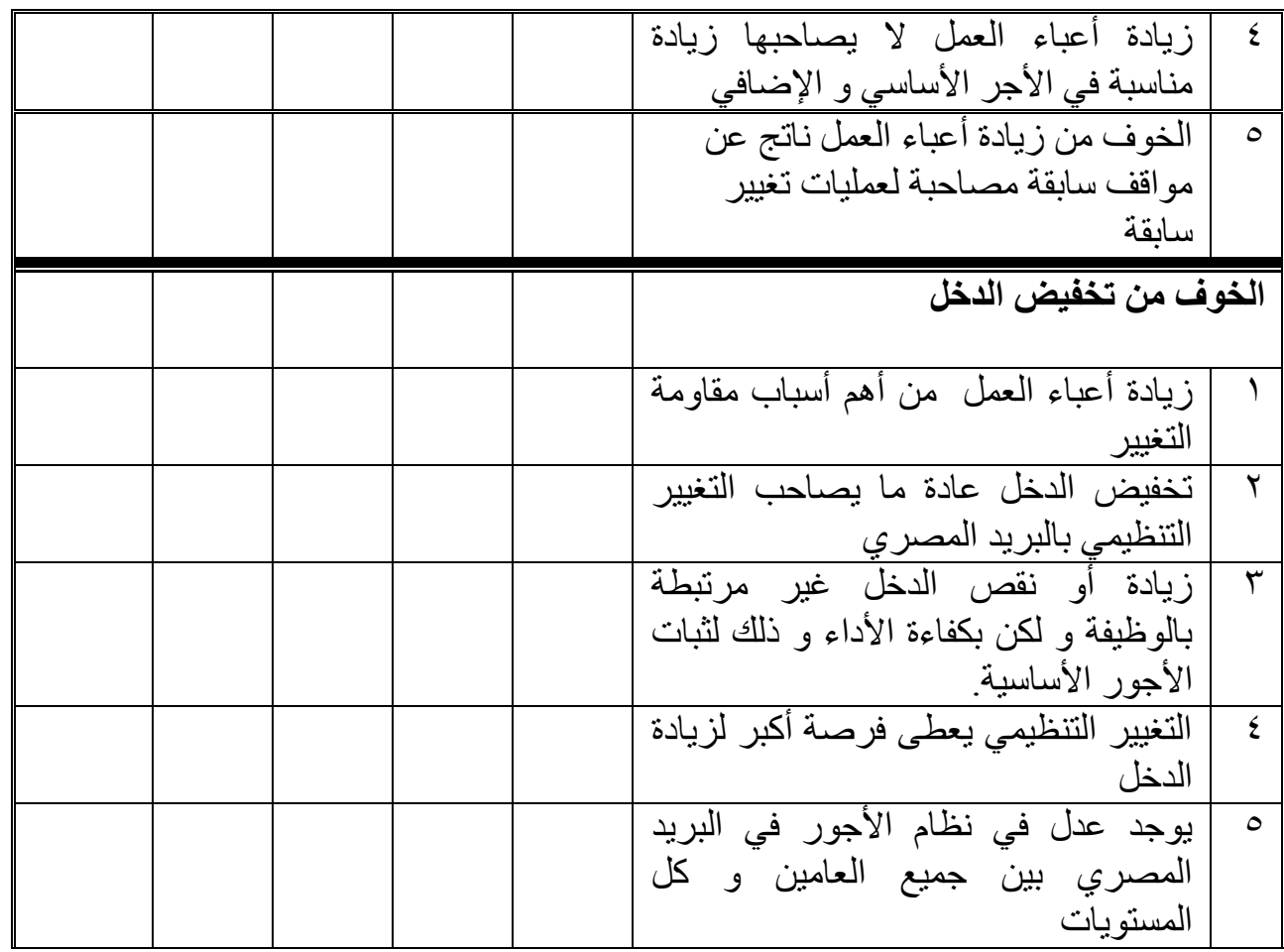

هل لايك ملاحظات أخرى على تطبيق القيادة التحويلية بالأكاديمية؟

شكر التعاونكم

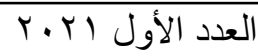




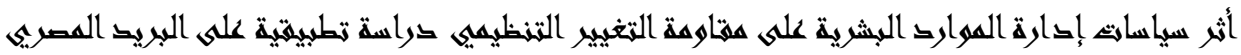

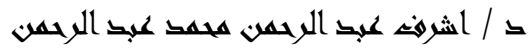

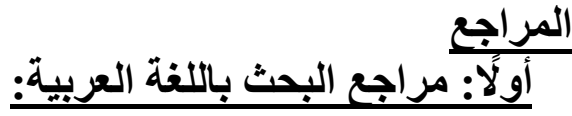

ا. ـ أحمد اليوسفي، رامز علي درويش،(ع ا ـ ب) أثر مقاومة التغيير على كفاءة أداء المنظمة: دراسة ميدانية على العاملين في مجلس مدينة اللاذقية. مجلة جامعة تشرين للبحوث

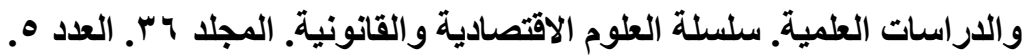

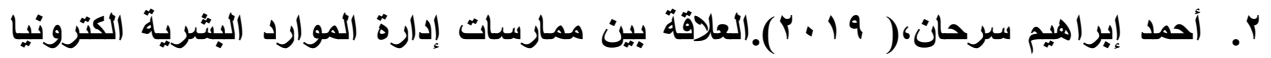
وتحقيق الاستدامة التنافسية بالتطبيق على الجامعة العراقية. رسالة ماجستير كلية التجارة.

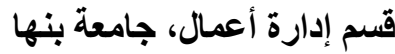

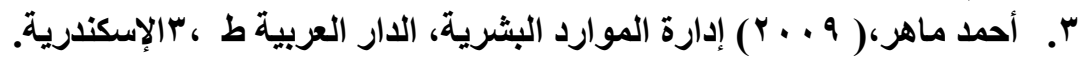

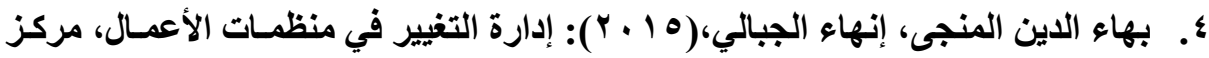

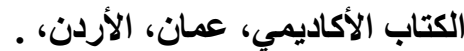

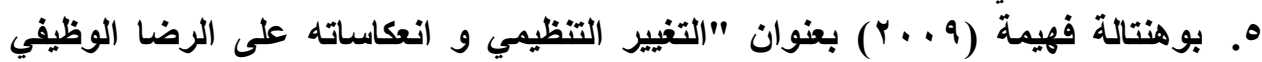
للعامل داخل المؤسسة الصناعية المخوصصة، " رسالة ماجستير في علم الاجتماع، جامعة ولة النة باتتة، .الجزائر

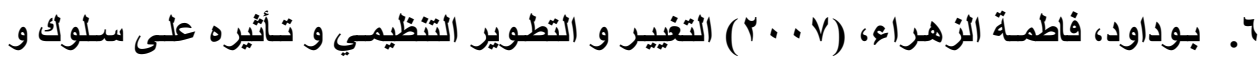
أداء

الأفراد في المنظمة. مذكرة ماجستير. جامعة بومرداس. الجزائر

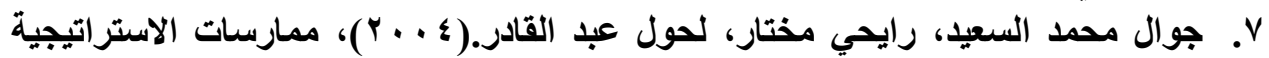
لإدارة الموارد البشرية ودورها في تحقيق التطوير التظظيمي: دراسة ميدانية في مديرية

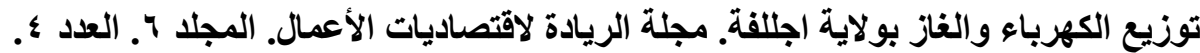

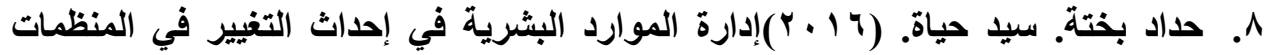

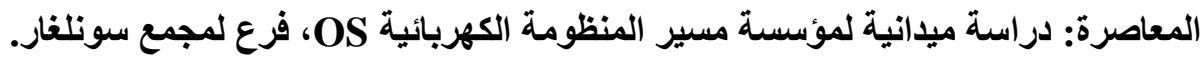
المجلة الجزائرية للعولمة والسياسات الاقتصادية. العدد 7.

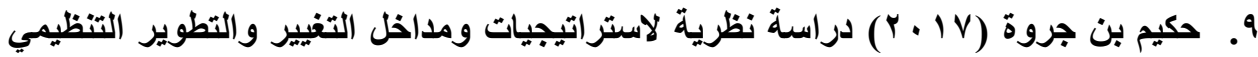

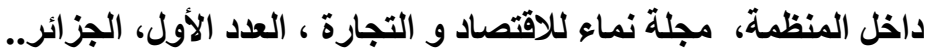




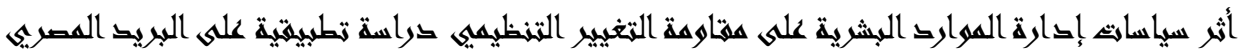

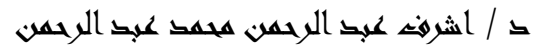

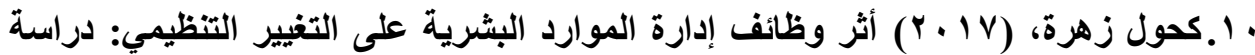

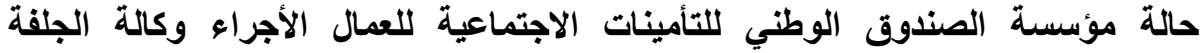

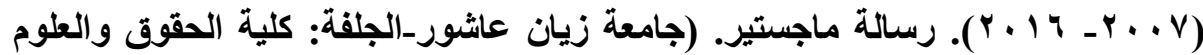
السياسية، قسم العلوم السياسية.

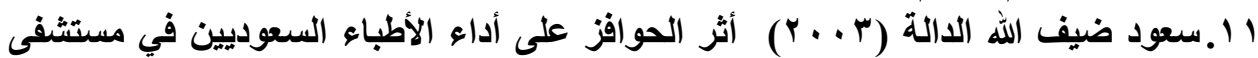
قوى الأمن بالرياض (ماجستير)--أكاديمية نايف العربية للعلوم الأمنية، كلية الدراسات العليا، قسم العلوم الإدارية

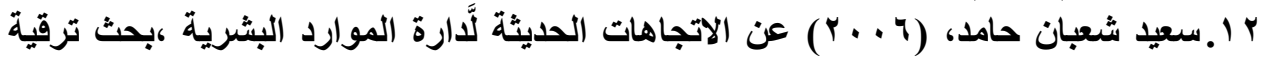

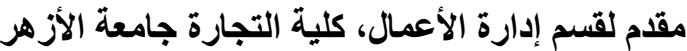

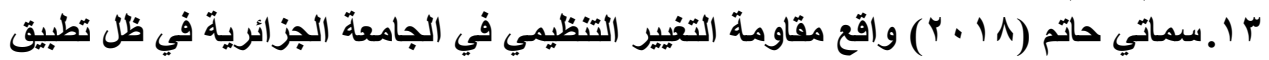
نظام (LMD) من وجهة نظر الأساتذة الجامعيين: دراسة ميدانية لكل من جامعتي تيارت

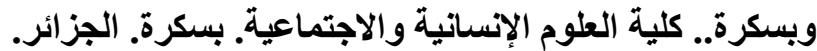

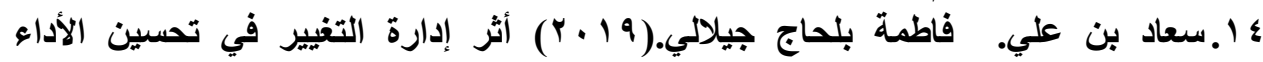
المؤسسي: دراسة حالة مؤسسة "باتيميتال. رسالة ماجستير. (جامعة الجيلالي: كلية

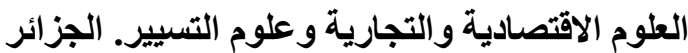

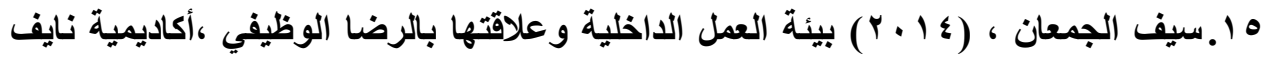
لاللعلوم الأمنية ، الرياض.

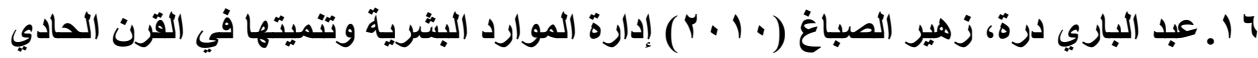

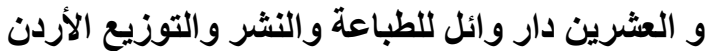

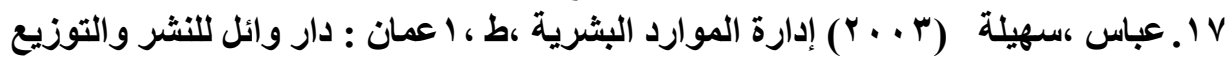

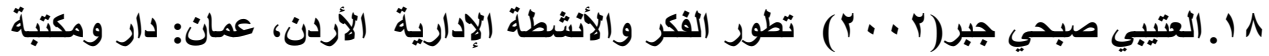

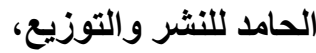

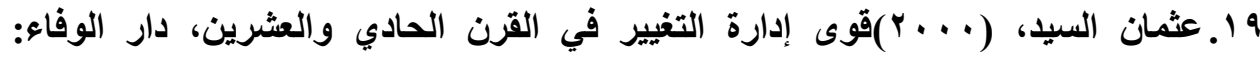

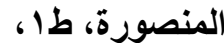

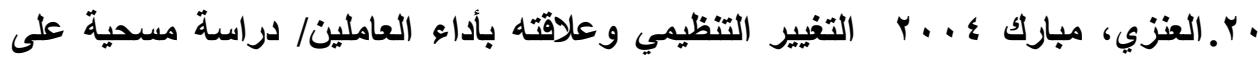
العاملين في إدارة مرور الرياض( الرياض: جامعة نايف العربية للعلوم الأمنية ) رسالة ماجستير

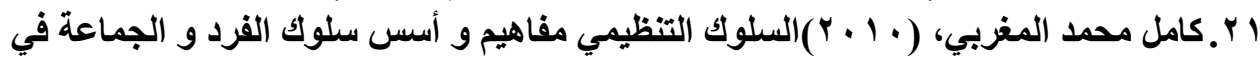

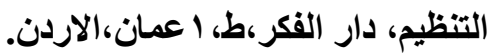




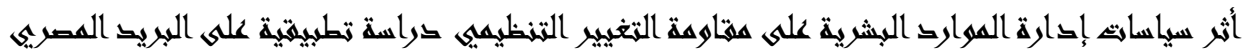

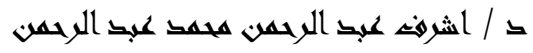

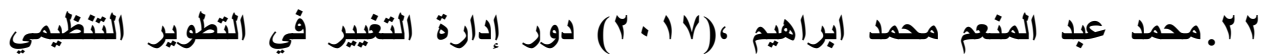
للمؤسسات الحكومية في المملكة العربية السعودية : دراسة تطبيقية علي بلاية محافظة المجمعة بمنطقة الرياض بالمملكة العربية السعودية.

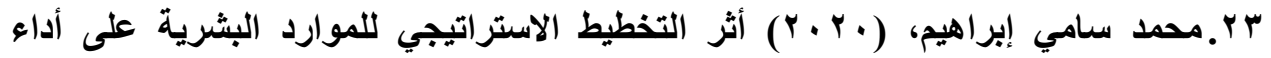
المنظمات: دراسة تطبيقية على مجموعة شركات العربي. رسالة ماجستير. (جامعة بنها:

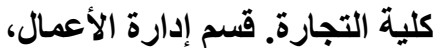

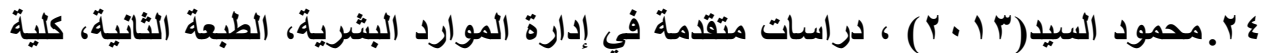

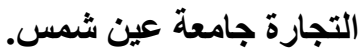

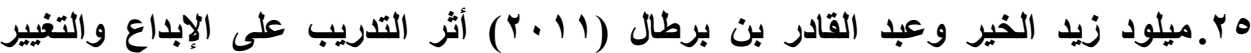
التظيمي كلية العلوم الاقتصادية و علوم التسييز جامعة سعد دحلب ــ الجزائر

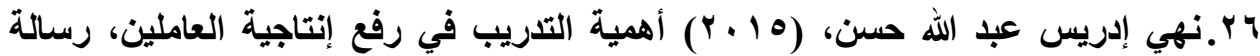

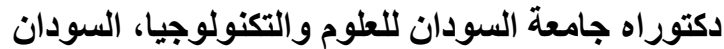

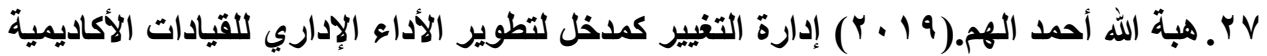
بالجامعات المصرية. مجلة جامعة الفيوم للعلوم التربوية والنفسية. العدد r I ـ الجزع الأهل الثالث

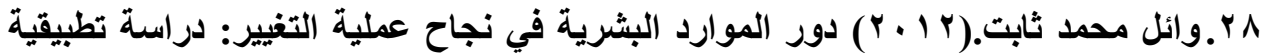
على المنظمات غير الحكومية العاملة في قطاع غزة ـفلسطين. مجلة جامعة الأزهر بغزة فئه

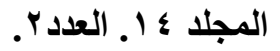

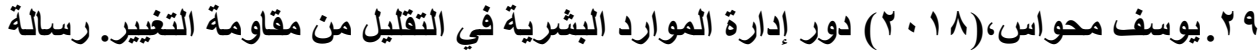
ماجستير. جامعة محمد بوضياف بالمسيلة: كلية العلوم الاقتصادية والتجارية وعلوم التسبيز. الجزائر.

\section{ثانيا: مراجع الدراسة باللغة الانجليزية:}

1. Arta JASHARI, Enver KUTLLOVCI, THE IMPACT OF HUMAN RESOURCE MANAGEMENT PRACTICES: MANUFACTURING ENTERPRISES IN KOSOVO, VGTU Press, Feb 2020.

2. A.H. Maslow (1943), A Theory of Human Motivation , Psychological Review, 50, 370-396.

3. Gary Dessler (2017) Human resource management, 15th edition Pearson Education, Inc. uk . 


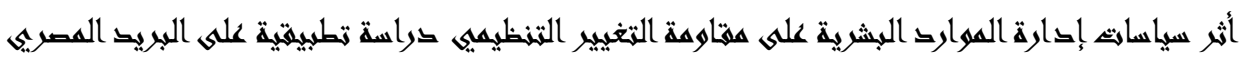

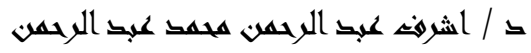

4. Robbins SP and Coulter M. (2007) Management. London: Pearson Prentice Hall.

5. Derek Torrington, Laura Hall, Stephen Taylor and Carol Atkinson ,(2014), human resource management, 9th Edition, Pearson Education Limited.UK.

6. Elnaga, A., \& Imran, A. (2013). The effect of training on employee performance. European journal of Business and Management, 5(4), 137-147.

7. Muthmainnah Mattjik et.al, Managing Human Resources In A Higher Education Institution: Managing The Lecturers, INTERNATIONAL JOURNAL OF SCIENTIFIC \& TECHNOLOGY RESEARCH, Jan 2020.

8. . Halit KARAXHA, METHODS FOR DEALING WITH RESISTANCE TO CHANGE, Baltic Journal of Real Estate Economics and Construction Management, 2019.

9. Ayesha Amjad, Muqqadas Rehman, RESISTANCE TO CHANGE IN PUBLIC ORGANIZATION: REASONS AND HOW TO OVERCOME IT, European Journal of Business Science and Technology, 2018. Available at:

10. Yunzhen Kuang, Managing resistance: The contribution of transformational leadership on followers' self-efficacy during incremental organisational change, 11th IBA Bachelor Thesis Conference, July 2018

11. Jaz Mehmood and Others: Role of Academic leadership in Change Management for Quality in Higher Education inPakistan, Journal of Education and Practice, Vol (3) ‘ No(16) , 2012.

12. Stephen Marshall: Change, Technology and Higher Education " Are Universities Capable of Organizational Change?، Research in Learning Technology, Vol (18) ‘No (3) 2011. Micheal Fullan: change forces Probing The Depths of Educational Reform, The Falmer Press, USA, 1993.

13. Ian McRoy \& Paul Gibs: Leading Change in Higher education, Education Management Administration Leader Ship , Vol(37), No(5), 2009. 


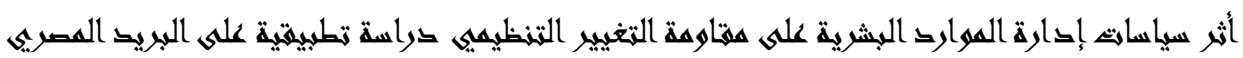

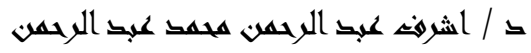

14. Jan. Andrews and Others: All change mangers, experience of organizational change in Theory and Practice, Journal oforganizational change management, vol(21), No(3),2008.

15. Ahmad Hafizh Damawan, Siti Azizah, Resistance to Change: Causes and Strategies as an Organizational Challenge, Advances in Social Science, Education and Humanities Research, 2019.'11

16. Forgues, B., Frechet, M., \& Josserand, E. (2006). interorganisational Relations. French management review, (5), 17-31

17. O'Reilly III, C. A., \& Tushman, M. L. (2013). Organizational ambidexterity: Past, present, and future. Academy of management Perspectives, 27(4), 324-338

18. Vakola, M., \& Nikolaou, I. (2005). Attitudes towards organizational change. Employee relations.

19. Udjo Eseroghene Franklin et.al, Obstacles, Resistance and Impact of Change in Organizations: An Examination of the Saudi Telecommunication Company (STC), International Journal of Academic Research in Business and Social Sciences, April 2016.

20. Tetiana Kuzhda, Diagnosing resistance to change in the change management process, Economics, Management and Sustainability, Nov2016.. Ir Muhammad Majid Khan, Determinants of Resistance to Organizational Change: A Qualitative Study of a Non-governmental Organization in Pakistan, Journal of Educational Leadership and Policy, Sep 2016

21. Ali El-Dirani et.al, The Role of Human Resources in Change Management: An Exploratory Study in Lebanon, The Journal of Middle East and North Africa Sciences, Page 2, 2019.

22. Muthmainnah Mattjik et.al, Managing Human Resources In A Higher Education Institution: Managing The Lecturers, INTERNATIONAL JOURNAL OF SCIENTIFIC \& TECHNOLOGY RESEARCH, Page 2360 , Jan 2020.

23. . Nur Izzah Mohd Radzi and Rozhan Othman, Resistance to Change: The Moderating Effects of Leader-Member Exchange and Role Breadth, Self-Efficacy, Journal of Advanced Management Science, Page 72 , Jan 2016.

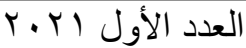

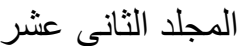




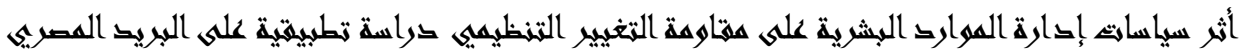

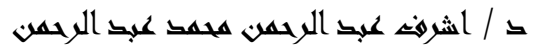

24. Palakh Jain et.al, Resistance to Change in an Organization, IOSR Journal of Business and Management (IOSR-JBM),Page 37 , May 2018. $1 \wedge$ Theory of constraints, Available at https://en.wikipedia.org/wiki/Theory_of_constraints,2020.

25. Hill, C., Jones, G. (2001). Strategic Management‘pg486. Houghton Mifflin, Boston.

26. Gareis ,R .(2010), “ changes of organizations by projects”, International Journal Of Project Management،Vol.28, pg.317-327.

27. Chiang, C.F. (2010),"perceived organizational change in the hotel industry an implication of change schema", International journal Of Hospitality Management, Vol 29,pg.157-167

28. Waddell ,N. and Sohal, A.(1998)," Resistance: a

29. constructive tool for change management", Management

30. Decision, Vol 36 No.6,pg 543-548

31. McGuinness, M. (2009). How to Motivate Creative People (Including Yourself). London: Creative Commons.

32. Burney, L., \& Widener, S. K. (2007). Strategic performance measurement systems, job-relevant information, and managerial behavioral responses-Role stress and performance. Behavioral Research in Accounting, 19(1), 43-69 